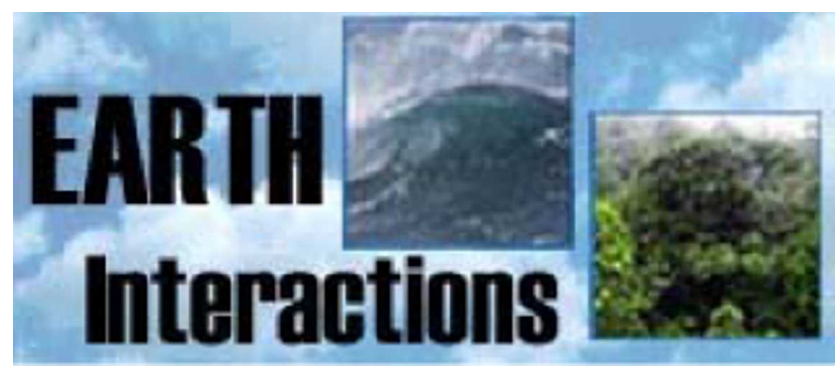

Copyright $($ C) 2007, Paper 11-002; 13,295 words, 7 Figures, 0 Animations, 9 Tables. http://EarthInteractions.org

\title{
The Tension between Fire Risk and Carbon Storage: Evaluating U.S. Carbon and Fire Management Strategies through Ecosystem Models
}

\section{M. Girod* and G. C. Hurtt}

Department of Natural Resources, Institute for the Study of Earth, Oceans, and Space, University of New Hampshire, Durham, New Hampshire

\section{S. Frolking}

Department of Earth Science, Institute for the Study of Earth, Oceans, and Space,

University of New Hampshire, Durham, New Hampshire

\section{J. D. Aber}

Department of Natural Resources, Institute for the Study of Earth, Oceans, and Space, University of New Hampshire, Durham, New Hampshire

\section{A. W. King}

Environmental Sciences Division, Oak Ridge National Laboratory, Oak Ridge, Tennessee

Received 19 December 2005; accepted 18 September 2006

* Corresponding author address: C. M. Girod, Department of Natural Resources, Institute for the Study of Earth, Oceans, and Space, University of New Hampshire, Durham, NH 03824.

E-mail address: cgirod@gmail.com 
Earth Interactions - Volume 11 (2007) - Paper No. 2 • Page 2

\begin{abstract}
Fire risk and carbon storage are related environmental issues because fire reduction results in carbon storage through the buildup of woody vegetation, and stored carbon is a fuel for fires. The sustainability of the U.S. carbon sink and the extent of fire activity in the next $100 \mathrm{yr}$ depend in part on the type and effectiveness of fire reduction employed. Previous studies have bracketed the range of dynamics from continued fire reduction to the complete failure of fire reduction activities. To improve these estimates, it is necessary to explicitly account for fire reduction in terrestrial models. A new fire reduction submodel that estimates the spatiotemporal pattern of reduction across the United States was developed using gridded data on biomass, climate, land-use, population, and economic factors. To the authors' knowledge, it is the first large-scale, gridded fire model that explicitly accounts for fire reduction. The model was calibrated to $1^{\circ} \times 1^{\circ}$ burned area statistics [Global Burnt Area 2000 Project (GBA-2000)] and compared favorably to three important diagnostics. The model was then implemented in a spatially explicit ecosystem model and used to analyze 1620 scenarios of future fire risk and fire reduction strategies. Under scenarios of climate change and urbanization, burned area and carbon emissions both increased in scenarios where fire reduction efforts were not adjusted to match new patterns of fire risk. Fuel reducing management strategies reduced burned area and fire risk, but also limited carbon storage. These results suggest that to promote carbon storage and minimize fire risk in the future, fire reduction efforts will need to be increased and spatially adjusted and will need to employ a mixture of fuel-reducing and non-fuel-reducing strategies.
\end{abstract}

KEYWORDS: Carbon storage; Fire model; Fire suppression

\title{
1. Introduction
}

Fire risk and carbon storage are linked by the fact that fire reduction results in carbon storage through the buildup of woody vegetation, and that stored carbon is a fuel for fires (Figure 1) (Murdiyarso et al. 2002; Williams et al. 2004; Spring et al. 2005). One region where this linkage is potentially a major concern is the United States (Hurtt et al. 2002). Historical reconstructions indicate that the burned area in the United States has fallen from more than $700000 \mathrm{~km}^{2} \mathrm{yr}^{-1}$ in the $1700 \mathrm{~s}$ to a contemporary 10-yr average of $24000 \mathrm{~km}^{2} \mathrm{yr}^{-1}$ (Leenhouts 1998; Houghton et al. 1999; NIFC 2005). This decrease in annual burned area has contributed to a growing land carbon sink (Houghton et al. 1999; Houghton et al. 2000; Pacala et al. 2001; Schimel et al. 2001), which has in turn led to an increased fire risk in at least some systems (Dodge 1972; Babbit 1995; Gutsell et al. 2001; Keeley and Fotheringham 2001; Pyne 2001; Allen et al. 2002; Dellasalla et al. 2004). The sustainability of the U.S. carbon sink and the extent of future fires thus depend in part on the effectiveness of future fire reduction activities (Hurtt et al. 2002).

Fire reduction can be partitioned into two types of activities: suppression and prevention. Suppression is defined as all the work of extinguishing or confining a fire beginning with its discovery (NWCG 1996). Fires can be confined and extinguished with fire retardants, fire suppressants, firebreaks, and backfires. Tools for fire discovery include fire towers, aircraft, and satellite imagery. Prevention is defined as activities directed at reducing the incidence of fires, including public education, law enforcement, and reduction of fuel hazards (fuels management) 


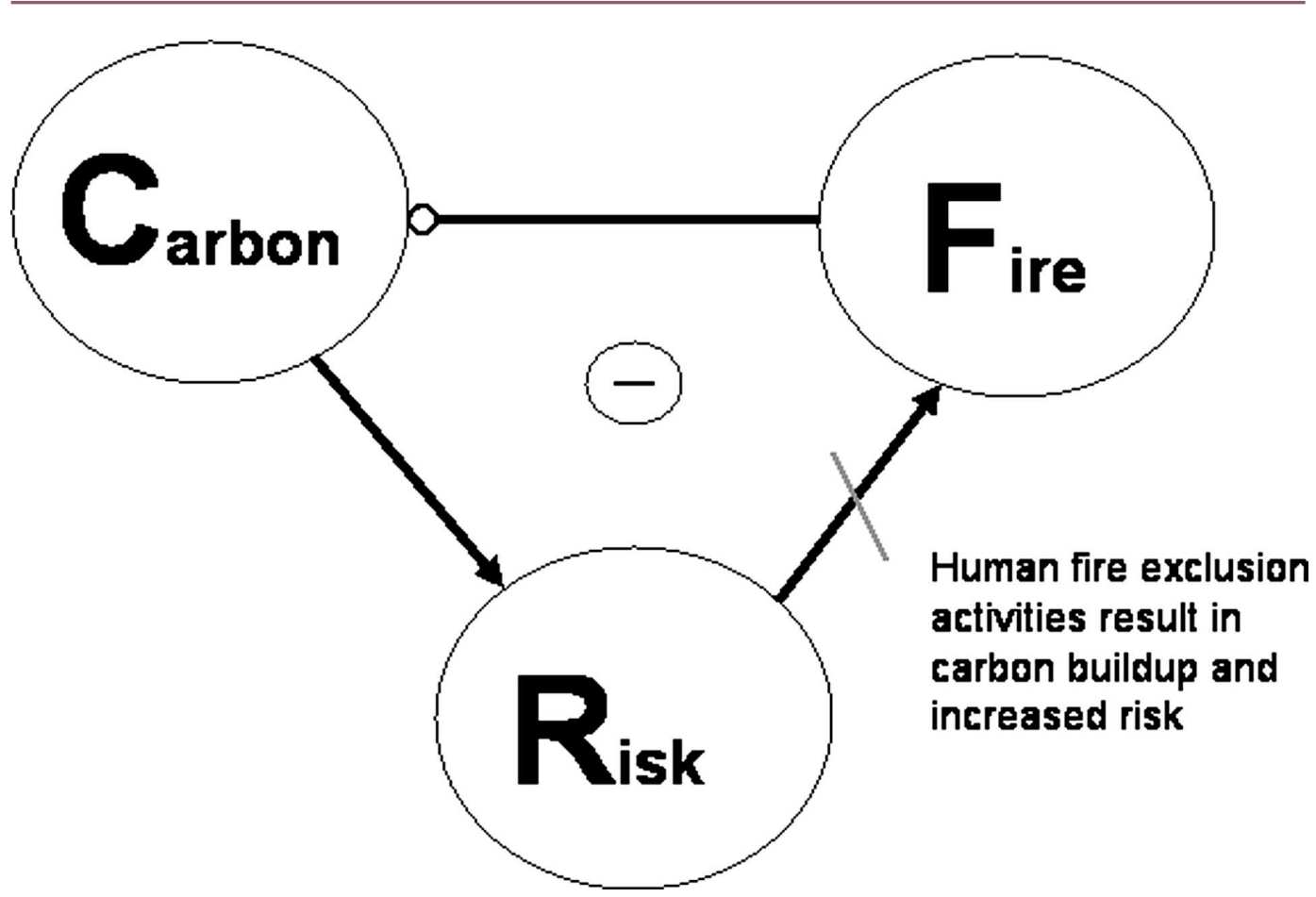

Figure 1. Feedback loop for carbon, fire, and risk. The solid arrowhead indicates a positive coupling, in which an increase in risk will lead to an increase in burned area. The circular arrowhead indicates a negative coupling, in which an increase in burned area will lead to a decrease in carbon stored in terrestrial ecosystems. This systems diagram represents a negative feedback loop because the system is self-regulating under natural conditions: carbon accumulation leads to increased fire risk, which leads to more burned area and reduces the carbon accumulation. Human intervention via fire exclusion has reduced burned area, which increases the carbon stored and in turn, fire risk.

(NWCG 1996). Public education campaigns and programs such as Smokey Bear, National Wildland Fire Prevention and Education Teams (http://www. firepreventionteams.us/), and Firewise (Firewise 2001) have been used to reduce human-caused ignitions and provide training in fuel reduction on the wildlandurban interface. Fuel reduction includes thinning trees, removing slash, logging, and performing prescribed burns with the intention to reduce fuel load (NWCG 1996).

Contemporary U.S. fire reduction employs a combination of suppression and prevention methods. The federal budget appropriation for fire-related spending through the National Fire Plan in 2005 is approximately \$2.5 billion (Alkire 2004). Around $70 \%$ of the funding goes to fire preparedness and suppression, while about $20 \%$ goes to hazardous fuel reduction (Alkire 2004). Hazardous fuel reduction is a main priority in the National Fire Plan's 10-Year Comprehensive Strategy (NFP 2001) and is also promoted by the Healthy Forests Initiative, which seeks to speed hazardous fuel reduction and forest restoration projects on certain federal lands by 
reducing paperwork and processing time (Healthy Forests Restoration Act of 2003). These alternative fire management strategies may have different impacts on fire risk, which could influence future fire reduction and carbon storage.

Models are needed to evaluate the effectiveness of fire reduction strategies in the future. Several large-scale terrestrial models have been developed to study the relationships among climate, fire, and carbon storage in ecosystems (Dale et al. 2001; Moorcroft et al. 2001; Keane et al. 1995; Nielson 1995; Bachelet et al. 2003; Sitch et al. 2003). For example, the Fire BioGeoChemical (Fire-BGC) process model used fire return intervals to calculate ignition probabilities; and used topography, weather, vegetation, and fuels to estimate fire size on scales from individual sites to landscapes (10 m-10 000 ha) (Keane et al. 1995). The Mapped Atmosphere-Plant-Soil System (MAPSS) fire model followed a rule-based algorithm that depended on fuel and ignition, where ignition is assumed to be related to growing season convective activity (Nielson 1995). MC1 is a landscape- to global-scale dynamic vegetation model in which fire occurrence was determined by fuel load, fuel arrangement, fuel moisture, and air temperature (Lenihan et al. 1998; Bachelet et al. 2001). The LPJ dynamic global vegetation model used a relationship between the daily litter moisture status and the length of the fire season to develop the function for probability of fire occurrence (Thonicke et al. 2001; Sitch et al. 2003). Although these models include carbon and fire, human influences on fire disturbance have generally not been considered.

In models that have incorporated human influences, the influences have generally been associated not with fire reduction, but with increased fire risk due to accidental or intentional ignitions. Venevsky et al. (Venevsky et al. 2002) included human ignitions, where the number of human ignitions was based on population density, lifestyle, and economic status. Some of these impacts have recently been included in the Lund-Potsdam-Jena (LPJ) model (C. M. G. Thonicke 2006, personal communication). Cardoso et al. (Cardoso et al. 2003) modeled fires as a function of precipitation, distance from roads, forest cover, and deforestation rate; closeness to roads and deforestation rate, both human factors, increased the fire occurrence. While these studies have shown that humans can be a significant source of fire in some regions, a challenge remains to explicitly include fire reduction activities in terrestrial models.

Two studies have incorporated fire reduction in terrestrial models. The first was an accounting-based reconstruction of carbon and fire dynamics for the coterminous United States aggregated by subregion (Houghton et al. 1999). The second imposed fire reduction in two gridded ecosystem models of the coterminous United States and bracketed the potential effectiveness of future fire reduction from current levels to complete failure (Hurtt et al. 2002). The range between these cases in the second study was large. Estimates of burned area ranged from approximately 20000 to $700000 \mathrm{~km}^{2} \mathrm{yr}^{-1}$, and the resulting carbon storage in U.S. ecosystems changed by $\pm 20 \mathrm{Pg} \mathrm{C}$ by 2100 . To refine these projections and evaluate alternative ecosystem management strategies, an explicit fire model is needed that is capable of estimating patterns of fire reduction, risk, and resulting burned area.

In this study, a new spatially explicit fire reduction model was developed based on data for the coterminous United States. The model was built by relating satellite information on burned area to the corresponding data on climate, biomass, and factors related to fire reduction. The resulting model was shown to reproduce 
statistics on contemporary fire patterns across the region. To estimate potential changes in the future and evaluate alternative ecosystem management strategies, the model was applied to a set of scenarios of possible future conditions.

\section{Model development and implementation}

The fire model that was developed is a modification of previously established fire submodels for the United States, which were components of the Ecosystem Demography (ED) and Miami Land-Use (MIAMI-LU) models (Hurtt et al. 1998; Moorcroft et al. 2001; Hurtt et al. 2002) (appendix A). These models differ, but both models estimate the annual rate of burned area, $F(x, y, t)\left(\mathrm{km}^{2} \mathrm{yr}^{-1}\right)$, with the following general functional form:

$$
F(x, y, t)=A(x, y, t) \times f_{F}(x, y, t) \times f_{C}(x, y, t) \times f_{R}(x, y, t),
$$

where $A(x, y, t)$ is the grid cell area $\left(\mathrm{km}^{2}\right), f_{F}(x, y, t)$ is a function of available fuel (assumed to be above-ground biomass density) $\left(\mathrm{yr}^{-1}\right), f_{C}(x, y, t)$ is a dimensionless function of climate, and $f_{R}(x, y, t)$ is a dimensionless function to estimate the effectiveness of fire reduction. Spatial position is referred to using the grid coordinates $x$ and $y\left(1^{\circ} \times 1^{\circ}\right.$ resolution), and time is referenced by $t$ (annual time step). Hurtt et al. (Hurtt et al. 2002) showed that both models reasonably simulate total burned area reconstructions in the coterminous United States from 1700 to present (Leenhouts 1998; Houghton et al. 1999; NIFC 2005).

To produce the new fire model, we modified the fuel $f_{F}(x, y, t)$ and reduction $f_{R}(x, y, t)$ functions. These two functions were chosen because they are sensitive to direct human activity. Although the dependence of fire risk on biomass and the influence of human activity on fire reduction are known to be important, the details of these dependencies are not well known or adequately described for large-scale spatially gridded studies. The challenge was to modify the functions of biomass and fire reduction given these uncertainties. To meet this challenge, we used a statistical model as a metric for "goodness of fit" (appendix B) and searched for parameters and functional forms that maximized the agreement between model estimates of burned area and data, while keeping the model as simple as possible. The model was implemented on a $1^{\circ} \times 1^{\circ}$ grid to estimate the total burned area in each grid cell for the year 2000 and compared to data on large fires $\left(>25 \mathrm{~km}^{2}\right)$ from the Global Burnt Area 2000 Project (GBA-2000) (Grégoire et al. 2003), which provided spatially resolved information on burned area for the entire coterminous United States. Gridded factors including population density, economic information, climate, land-use type, and above-ground biomass density were utilized as inputs (Table 1). Several additional inputs were tested but did not improve accuracy. In all, more than 100 model forms and $10^{7}$ parameter combinations were tested before arriving at the final model (described below, in appendix $\mathrm{C}$, and Table 2).

\subsection{Fuel}

In the original fire submodels, the yearly rate of burned area increases linearly with fuel density. The positive dependence of fire on fuel was consistent with studies that have compared fire data to time since fire (Li et al. 1997; McCarthy 
Earth Interactions - Volume 11 (2007) - Paper No. 2 • Page 6

Table 1. Input datasets for fire model.

\begin{tabular}{|c|c|c|}
\hline Dataset & Source & Format \\
\hline $\begin{array}{l}\text { Above-ground } \\
\text { biomass }\end{array}$ & $\begin{array}{l}\text { MIAMI-LU outputs (Meeson et al. 1995; } \\
\text { Sellers et al. 1995) }\end{array}$ & $\mathrm{kg} \mathrm{C} \mathrm{m}{ }^{-2}$ \\
\hline Land-use variables & $\begin{array}{l}\text { Land-use history reconstruction } \\
\text { (Ramankutty and Foley 1999; } \\
\text { Houghton et al. 1999) }\end{array}$ & $\begin{array}{l}\text { Percent area of crop, pasture, } \\
\text { plantation, forest, and } \\
\text { secondary land }\end{array}$ \\
\hline $\begin{array}{l}\text { Annual mean } \\
\text { climate }\end{array}$ & $\begin{array}{l}\text { NCEP-NCAR reanalysis project } \\
\text { (Kistler et al. 2001; NOAA-CIRES 2005) }\end{array}$ & $\begin{array}{l}\text { Temperature: }{ }^{\circ} \mathrm{C} \\
\text { Precipitation: } \mathrm{mm} \mathrm{yr}^{-1}\end{array}$ \\
\hline Economic inputs & Bureau of Economic Analysis (BEA 2004) & Gross state product: $\$ 10^{6}$ in 2004 \\
\hline Population density & U.S. Census Database 2000 (National Atlas 2004b) & People per $\mathrm{km}^{2}$, aggregated to $1^{\circ}$ \\
\hline
\end{tabular}

et al. 2001). Other studies support evidence of nonlinear relationships, including exponential, sigmoid, and logistic functions (Li et al. 1997; Malamud et al. 1998; Grissino-Mayer 1999; Schoenberg et al. 2003). Based on these studies, each of these functional forms was evaluated in the fuel function, $f_{F}(x, y, t)$. The final form [Equation (2)] was simple and produced more accurate fire estimates than the other functional forms. Equation (2) represents the idea that burned area increases nonlinearly with fuel so that burned area begins to saturate as fuel levels grow (McCarthy et al. 2001; Schoenberg et al. 2003):

$$
f_{F}(x, y, t)=p\left[1-e^{B(x, y, t)}\right] .
$$

In this equation, $B(x, y, t)$ is above-ground biomass density $\left(\mathrm{kg} \mathrm{C} \mathrm{m}^{-2}\right)$ and $p$ is a parameter that governs the maximum burned area $\left(p=0.001 \mathrm{yr}^{-1}\right)$.

\subsection{Reduction}

The original reduction function, $f_{R}(x, y, t)$, used in ED and MIAMI-LU reduced the annual burned area in each grid cell proportionally to match historical esti-

Table 2. Parameter values for MIAMI-LU model; see Equation (6). The column labeled "Best" contains the best (highest likelihood) parameter values found using the data fitting algorithm and likelihood metric described in appendix B. Columns under the heading "All" contain the range of parameter values found within 12.592 log-likelihood points from the maximum (5\% significance level, and 6 degrees of freedom) (Brower and Zar 1984), allowing all parameters to vary simultaneously. The columns under the heading "Single" contain the analogous range of parameter values keeping all other focal parameter values fixed at their best values. Parameters with narrower ranges are more sensitive than parameters with wider ranges.

\begin{tabular}{clcccccc}
\hline \multirow{2}{*}{$\begin{array}{c}\text { MIAMI-LU } \\
\text { parameter }\end{array}$} & \multicolumn{1}{c}{ Units } & \multicolumn{3}{c}{ All } & & \multicolumn{2}{c}{ Single } \\
\cline { 3 - 4 } \cline { 7 - 7 } \cline { 6 - 7 } & & Best & Low & High & & Low & High \\
\hline$p_{1}$ & Population density km ${ }^{-2}$ & 5.43 & 0.892 & 20.2 & & 1.28 & 14.1 \\
$p_{2}$ & $\mathrm{~kg} \mathrm{C} \mathrm{m}^{-2}$ & $5.13 \times 10^{-5}$ & $1.82 \times 10^{-6}$ & $7.81 \times 10^{-3}$ & & $4.77 \times 10^{-6}$ & $6.31 \times 10^{-6}$ \\
$p_{3}$ & Dimensionless & 4.93 & 1.78 & 5.86 & & 4.88 & 5.06 \\
$p_{4}$ & Dimensionless & 2.43 & 0.762 & 2.75 & & 2.38 & 2.52 \\
$p_{5}$ & $\mathrm{~kg} \mathrm{C} \mathrm{m}^{-2}$ & $5.82 \times 10^{-4}$ & $5.44 \times 10^{-6}$ & 29.8 & & $4.04 \times 10^{-4}$ & $1.49 \times 10^{-2} *$ \\
$p_{6}$ & Dimensionless & 1.85 & $1.00 \times 10^{-7}$ & 7.45 & & 1.64 & $2.85^{*}$ \\
$p_{7}$ & Dimensionless & 2.78 & $1.00 \times 10^{-7}$ & 3.85 & & 2.59 & $4.38^{*}$ \\
\hline
\end{tabular}

* Past this maximum value, the parameter does not affect the model output - the likelihood does not change at higher parameter values. 
Earth Interactions • Volume 11 (2007) • Paper No. 2 • Page 7

mates of total burned area. To improve on this formulation, a model was developed where the effectiveness of fire reduction depends on both fuel and human activity. Human activity was assumed to modify a threshold for fuel, below which fire reduction was effective, and above which it was ineffective. In particular, $f_{R}(x, y, t)$ was parameterized best as a logistic function of above-ground biomass in which higher output values indicate greater burned area [Equation (3); Figure 2]. A logistic function has several basic shape parameters (Beltrami 1987). We concentrated on the parameters for the location of the inflection point $\left(B^{*}\right)$, and the height of the asymptote $(K)$.

$$
f_{R}(x, y, t)=K(x, y, t) \times \frac{1}{1+e^{-\left[B(x, y, t)-B^{*}(x, y, t)\right]}}
$$

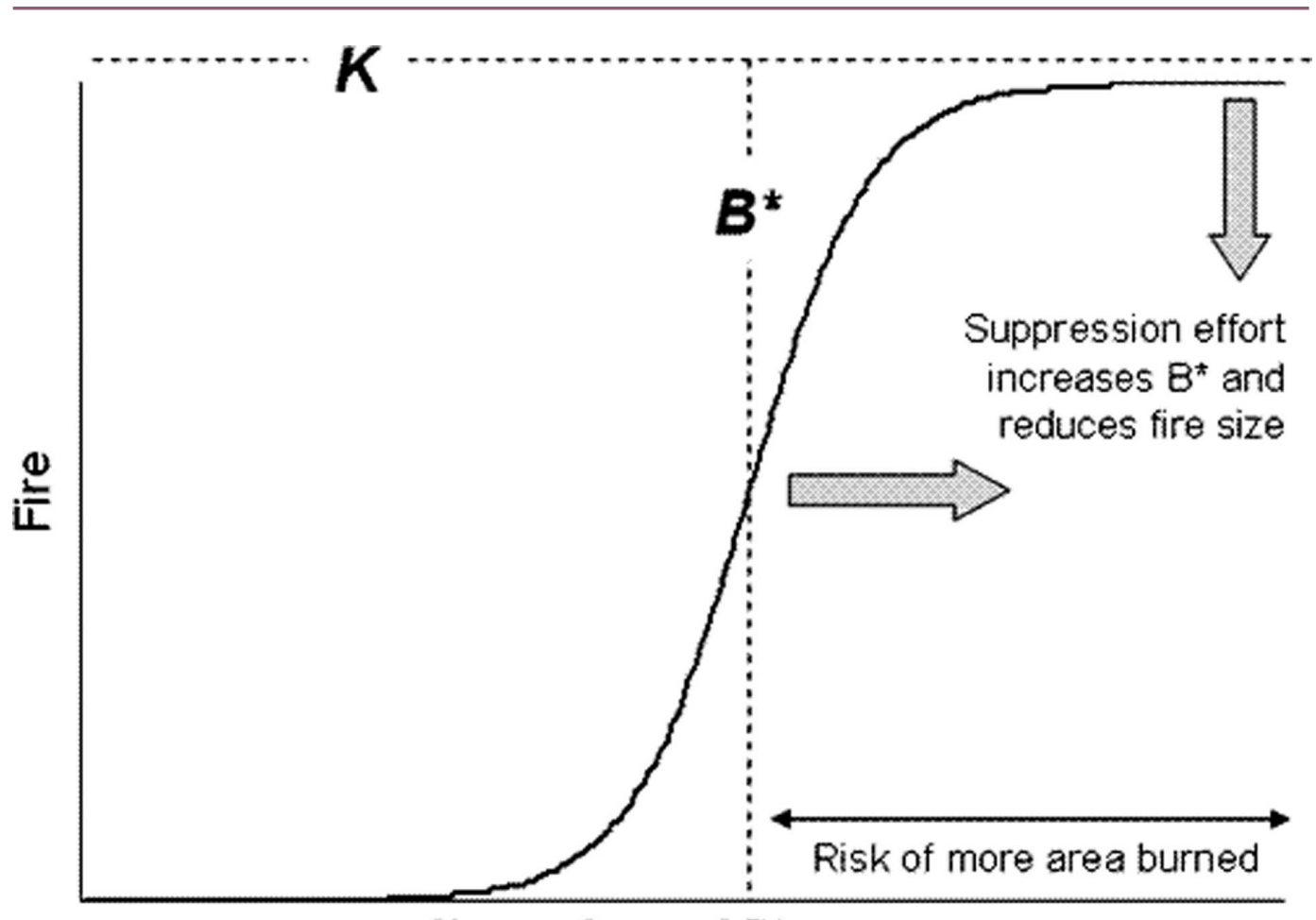

\section{Above Ground Biomass}

Figure 2. Reduction function from modified MIAMI-LU fire submodel. The new reduction function, $f_{R}(x, y, t)$, includes a logistic function of biomass that modifies the burned area from the natural fire function. The biomass threshold $\left(B^{*}\right)$ represents the level of above-ground biomass at which reduction becomes ineffective, leading to greater burned area. The asymptote $(K)$ represents the minimum influence of fire reduction on burned area. The effect of reduction is to increase the biomass threshold value and decrease the height of the asymptote, thus limiting the size and occurrence of fires. The level of biomass relative to the biomass threshold is an indicator of fire risk, since a larger burned area is likely if the biomass exceeds the biomass threshold $\left(B>B^{*}\right)$. Note that risk refers to the risk of ineffective fire reduction, rather than risk of fire in general. 
Earth Interactions • Volume 11 (2007) - Paper No. 2 • Page 8

In this model, the biomass threshold $\left(B^{*}\right)$ represents the level of above-ground biomass at which reduction becomes ineffective, leading to greater burned area. The asymptote $(K)$ represents the minimum influence of fire reduction on burned area. In the absence of human activity (maximum burned area), the biomass threshold is 0.0 and the asymptote is 1.0 since there is no reduction occurring. The effect of reduction is to increase the biomass threshold value and decrease the height of the asymptote, thus limiting the size and occurrence of fires.

\section{Spatial variability of fire reduction}

In general, the mechanisms of fire reduction are heterogeneous and spatially variable. Our approach assumed that the fire reducing effects of these activities could be inferred by various related inputs including population density, state funding, climate, and land-use activities. Several additional factors were also tested, such as total fire towers per grid cell (National Historic Lookout Register 2004), percent federal lands (National Atlas 2004a), and information on humancaused versus natural fire ignition (Schmidt et al. 2002), but they did not improve model results. The factors that did improve model results were used in functions to determine the height of the asymptote $(K)$ and the value of the biomass threshold $\left(B^{*}\right)$. Land-use information was also used to allow for different degrees of fire reduction on different land-use types. Each of the elements of the model is addressed in turn.

In the final form of the model, the height of the asymptote was modeled as inversely related to population density,

$$
K(x, y, t)=\frac{p_{1}}{H(x, y, t)+p_{1}},
$$

where $H(x, y, t)$ is the population density (people $\mathrm{km}^{-2}$ ) and $p_{1}$ is a shape parameter. The inverse dependence of $K$ on population was assumed to represent a mixture of different fire reduction activities. Wildland-urban interface programs like Firewise (Firewise 2001), priority funding for fuel reduction available for the Communities at Risk program (Department of Agrigulture and Department of the Interior 2001; NASF 2002), and a history of fire exclusion to protect property (Parsons 1981) suggest that highly populated areas are likely to invest in fire suppression and prevention. In addition, higher population density may be related to improved access for fighting fires, and structures such as roads that act as firebreaks. Several simple inverse functions were tested for $K$, and Equation (4) yielded the best results.

The magnitude of the biomass threshold $\left(B^{*}\right)$ was assumed to be based on an index of per capita wealth. It was also assumed that fire reduction effort was efficiently allocated to fire-prone areas. These assumptions were motivated by the trend in which private property and wealth increase reduction efforts by increasing the social and political pressures to extinguish fires at all costs (National Fire Plan 2004). Programs such as the Wildland Fire Assessment System are used to identify fire-prone areas, based on climate variables (Burgan et al. 1997; Kaufman et al. 2003). Analogous to the development of other functions described above, simple functions describing these phenomena were tested, and the function that yielded the best results was implemented: 


$$
\begin{aligned}
& \text { Earth Interactions }- \text { Volume } 11(2007) \cdot \text { Paper No. } 2 \text { Page } 9 \\
& \qquad B^{*}(x, y, t)=p_{2} \times\left(\ln f_{C}\right)^{p_{3}} \times\left\{\ln \left[\frac{G(x, y, t)}{H(x, y, t)}\right]\right\}^{p_{4}}
\end{aligned}
$$

where $G(x, y, t)$ is the gross state product (GSP) $\left(10^{6} \$\right)$ and $p_{2}, p_{3}$, and $p_{4}$ are parameters; $H(x, y, t)$ was defined previously as the population density (people per square kilometer). In this function, an increase in perceived climatic risk, $f_{C}(x, y, t)$, and per capita wealth will increase the threshold.

By this formulation, the level of biomass relative to the biomass threshold is an indicator of fire risk, since a greater burned area is likely if the biomass exceeds the threshold $\left(B>B^{*}\right)$. Hereafter, we refer to grid cells at risk of fire as those in which the biomass level is greater than the biomass threshold. Note that "risk" refers to the risk of ineffective fire reduction, rather than risk of fire in general.

Finally, alternative land-use activities were assumed to influence fire reduction differently. In particular, the fire reduction effort was allowed to differ among levels of land management intensity. Burned area on cropland was not simulated because as wildlands are converted to agricultural lands, fire tends to be eliminated (Houghton et al. 2000; Hurtt et al. 2002). In fact, the fires that do occur on croplands are generally not wildfires, but instead are caused by human ignitions (Korontzi et al. 2006). Pasture and plantation lands were assumed to have an intermediate level of management. Primary and secondary lands were assumed to have the lowest levels of fire management. To allow the fire reduction effort to differ, the biomass threshold was parameterized separately for each of the levels of management intensity.

\subsection{Model diagnostics and validation}

Following model development, several model diagnostics were compared to observations, and the model was validated with independent data. The model estimate of total burned area over the coterminous United States was $35671 \mathrm{~km}^{2}$ in 2000, compared to an observed total of $30290 \mathrm{~km}^{2}$ (GBA-2000). Although the estimate of total burned area was somewhat high, the overprediction was confined to a very small percentage of the domain. The estimated size distribution of burned area compared favorably to observations (Figure 3a). In the data, 99\% of the grid cells had burned area between 0 and $525 \mathrm{~km}^{2}$, accounting for $23342 \mathrm{~km}^{2}$ of the total burned area. The corresponding estimates from the model were that $98 \%$ of the grid cells had burned area in this range, totaling $23702 \mathrm{~km}^{2}$. Very large burned areas $\left(>525 \mathrm{~km}^{2}\right)$ were relatively rare and were a greater challenge to estimate. In the data, less than $1 \%$ of the grid cells had burned area between 525 and $1750 \mathrm{~km}^{2}$, accounting for $6948 \mathrm{~km}^{2}$ of the total burned area. The corresponding estimates from our model were less than $2 \%$ of grid cells with burned area in this range, totaling $11392 \mathrm{~km}^{2}$.

A second class of diagnostics involved the comparison of the observed and modeled spatial distribution of burned area. In general, the modeled spatial distribution of burned area compared favorably with observations (Figures 3c-d). For example, both the model and data had substantial burned area in the Northwest. They also both showed relatively little burned area in the Northeast. There is some indication that the model overpredicted burned area in the Southeast. To quantitatively compare the spatial patterns, the distribution of differences was computed 

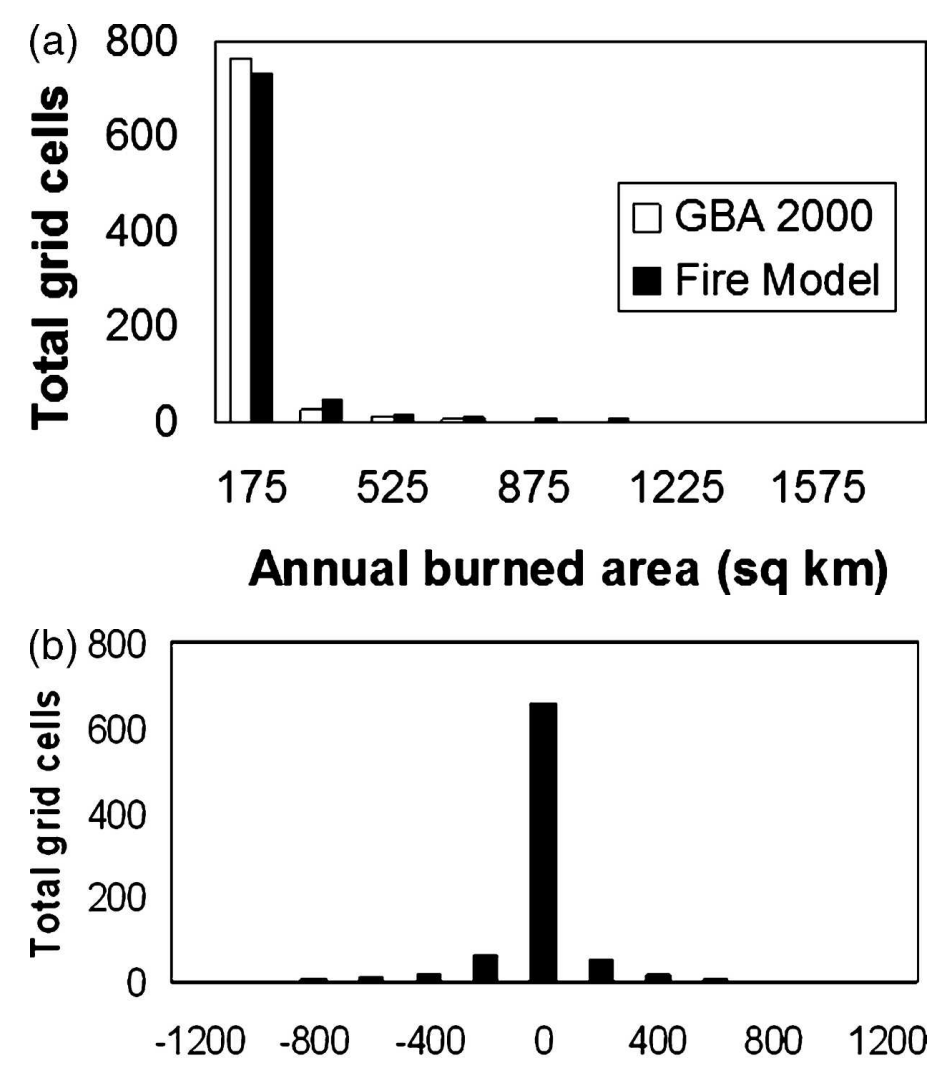

Difference of annual burned area (sq $\mathrm{km}$ )

(c)

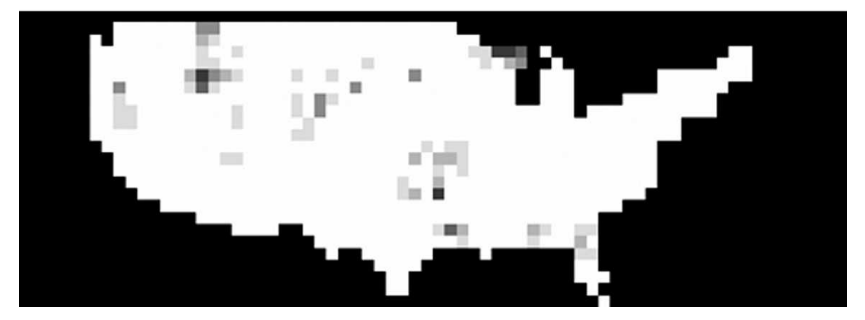

(d)

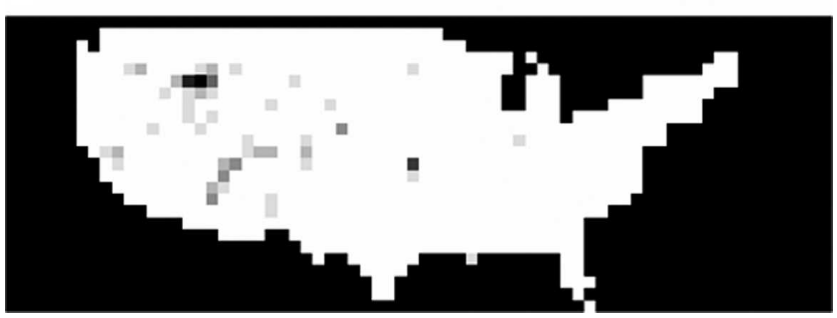

sq km

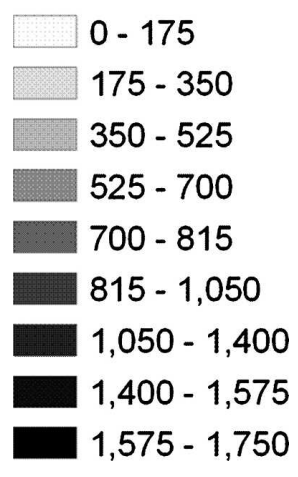

Figure 3. Burned area in the United States for the year 2000. (a) Comparison of the fire size distribution of the model estimates and satellite data. (b) The distribution of differences between model and satellite annual burned area by grid cell. Maps of the burned area $\left(\mathrm{km}^{2}\right)$ per $1^{\circ} \times 1^{\circ}$ grid cell (c) estimated by the model and (b) reported by the GBA-2000 Project. 
between model estimates and observed burned area in each grid cell (Figure 3b). While the model overpredicted the burned area in some areas, and underpredicted in other areas, the mode of the distribution of the differences (observed - modeled) was near 0 , indicating that there was no bias in the distribution.

Finally, it was also desirable to validate the model with an independent dataset. For this, we used a time series of digitized burned area data reported by federal agencies managing much of the western wild lands for the years 1980-2000 (Westerling et al. 2003). Model estimates were computed over the western United States using climate data from the National Centers for Environmental PredictionNational Center for Atmospheric Research (NCEP-NCAR) reanalysis project (NOAA-CIRES 2005), and then compared to the burned area data over the same time period. For the year 2000, the estimate of total burned area $\left(17373 \mathrm{~km}^{2}\right)$ was $11 \%$ less than observations $\left(19548 \mathrm{~km}^{2}\right.$ ). In the period from 1991 to 2000, the model underestimated the annual burned area for 3 of the 10 years and accurately estimated the direction of change in 7 of these years (Figure 4). While the interannual variability provides a good validation of the complete fire model, it likely emphasizes climate sensitivity more than fire reduction effects, which are generally less temporally variable.

\section{Projections of the future}

Since the sustainability of the U.S. carbon sink and the extent of future fires depend in part on the effectiveness of future fire reduction activities, it is important

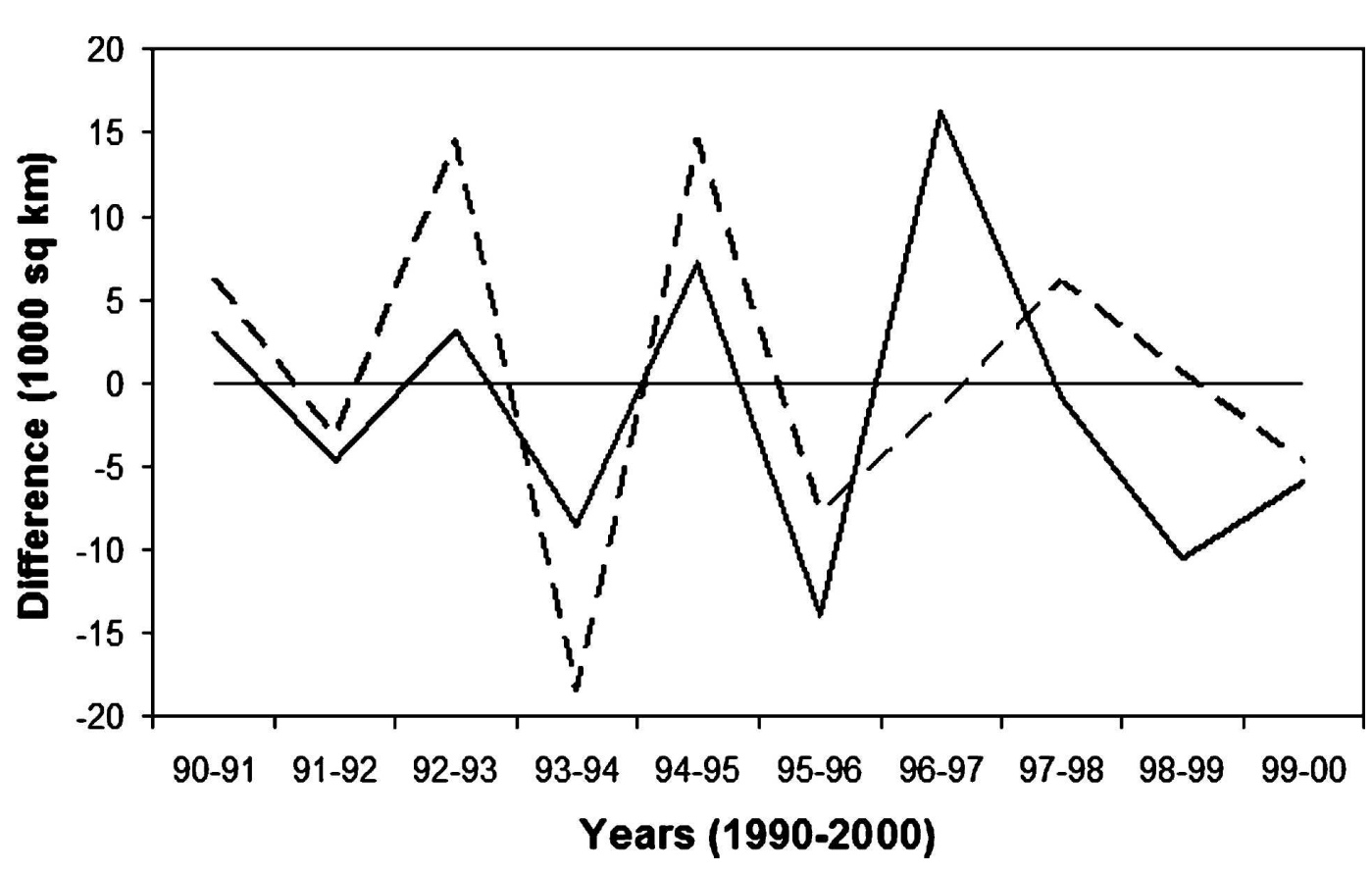

Figure 4. Year-to-year differences in annual burned area in regions over much of the western wildlands (Westerling et al. 2003) for model estimates (dashed line) and ground data (solid line). Each point was computed by subtracting the previous year's burned area from the current year's burned area. 
to evaluate alternative reduction activities in the context of carbon storage and burned area. To address questions about the effectiveness of alternative fire management strategies, a set of future scenarios was designed and used as input in MIAMI-LU using the modified fire submodel over the coterminous United States. Projections of the future (2010-2100) were then analyzed in terms of burned area, carbon stored, and risk of future fires. To add confidence to model results, a subset of scenarios was run in a second ecosystem model (ED) also using the new fire reduction function.

\subsection{Scenarios}

Seven major factors were identified that could change the magnitude and spatial pattern of burned area: catastrophic fire reduction failure, land-use management, climate change, adaptiveness of fire reduction to climate change, population density, per capita wealth, and fuel reduction (Table 3). For the creation of the scenarios, each of these factors had between two and four different cases that specified how the factor could change in the future. All factors included a "no change" case for comparison. Using different combinations of cases, a family of 1620 scenarios was produced. The cases are described below.

The first major factor considered was the potential catastrophic failure of future fire reduction activities. Artificial exclusion of fire from U.S. ecosystems has led

Table 3. Model factors and scenarios.

\begin{tabular}{|c|c|}
\hline Model factor & Scenarios \\
\hline S: Reduction failure & $\begin{array}{l}\text { S0: Fire reduction does not fail-biomass threshold does not change } \\
\text { S1: Fire reduction fails completely_-fire returns to natural burned area } \\
\text { S2: Fire reduction fails partially_biomass threshold reduced by half }\end{array}$ \\
\hline L: Land use & $\begin{array}{l}\text { L0: All land-use types have same fire reduction activities } \\
\text { L1: Changes in fire reduction activities take place on primary and secondary } \\
\text { lands only } \\
\text { L2: Changes in fire reduction activities take place on pasture and plantation } \\
\text { lands only }\end{array}$ \\
\hline C: Climate change & $\begin{array}{l}\text { C0: No change-constant climate } \\
\text { C1: Temperature only linear increase by } 2100 \\
\text { C2: Temperature and precipitation linear increase by } 2100\end{array}$ \\
\hline A: Adaptive fire reduction & $\begin{array}{l}\text { A0: Pattern of fire reduction stays same } \\
\text { A1: Fire reduction matches new pattern of fire risk resulting from change } \\
\text { in climate }\end{array}$ \\
\hline P: Population density & $\begin{array}{l}\text { P0: No change-constant population density } \\
\text { P1: Population density increases at a rate of } 0.7 \% \mathrm{yr}^{-1} \text { until } 2050 \text {, then at a } \\
\text { rate of } 0.1 \% \mathrm{yr}^{-1} \\
\text { P2: Population density declines in rural areas at rate of } 0.06 \% \mathrm{yr}^{-1} \text { and } \\
\text { remaining increase from population growth distributed among urban areas }\end{array}$ \\
\hline $\begin{array}{l}\text { G: Gross state product } \\
\text { per capita }\end{array}$ & $\begin{array}{l}\text { G0: No change-constant GSP per capita } \\
\text { G1: GSP per capita increases at rate of } 2.44 \% \mathrm{yr}^{-1} \text { until 2030, then at a rate of } \\
2.98 \% \mathrm{yr}^{-1}\end{array}$ \\
\hline F: Fuel reduction & $\begin{array}{l}\text { F0: No fuel reduction employed } \\
\text { F1: Fuel reduction everywhere, at a rate of } 0.22 \% \mathrm{yr}^{-1} \\
\text { F2: Thinning in high risk areas only, at a rate of } 0.8 \% \mathrm{yr}^{-1} \text { by } 2003 \\
\text { F3: Thinning in high risk and high population density areas only, at a rate of } \\
\quad 0.8 \% \mathrm{yr}^{-1} \text { by } 2003\end{array}$ \\
\hline
\end{tabular}


Earth Interactions • Volume 11 (2007) • Paper No. 2 • Page 13

to an increased fire hazard in fire-prone forests (Pyne et al. 1996; Allen et al. 2002). Globally, wildfires can have a large impact on carbon storage (Langenfelds et al. 2002; Schimel and Baker 2002; Page et al. 2002; van der Werf et al. 2004), and at the national scale, model estimates indicate that catastrophic failure would result in large changes in carbon storage and burned area (Hurtt et al. 2002). To address this issue, two cases were evaluated. Total failure was simulated by setting the biomass threshold $\left(B^{*}\right)$ to $0.0 \mathrm{~kg} \mathrm{C} \mathrm{m}^{-2}$ and the height of the asymptote $(K)$ to 1.0. Partial failure was simulated by halving the biomass threshold and doubling the height of the asymptote.

The second major factor considered was the influence of land management intensity on future fire reduction activities. The hypothesis underlying this factor was that different levels of land management intensity may correspond to different degrees of future fire reduction activities.

In the first case considered, future changes in human activities that affect fire were applied only to the most intensively managed lands (pasture and plantation). In the second case, these changes were applied only to less managed lands, which generally contain more biomass (primary and secondary). The third case allowed for changes to future fire reduction activities to occur on all land-use types.

In previous studies, climate change has been shown to affect the distribution and extent of future burned area (Kasischke et al. 1995; Dale et al. 2001; Bachelet et al. 2003, Brown et al. 2004). To estimate the consequences of changes in climate, two cases were considered: an increase in temperature and an increase in both temperature and precipitation. These cases were chosen to isolate the effects of each factor on fire activity. Temperature and precipitation projections were taken from the Hadley and Coupled Global Climate Model version 1 (CGCM1) climate models (National Assessment Synthesis Team 2001). Hadley and CGCM1 predict a $2.6^{\circ}$ and $5.0^{\circ} \mathrm{C}$ increase in temperature, and a 168 - and $107-\mathrm{mm}$ increase in yearly precipitation by 2100 , respectively. Every case was considered separately under each of the climate scenarios.

Given that climate change can potentially affect future patterns of burned area, it may be desirable to adjust human fire reduction activities to match the new patterns of fire risk. To identify the importance of this adjustment, we simulated adaptive fire reduction and nonadaptive fire reduction. Adaptive fire reduction matched the pattern of fire reduction to the pattern of fire risk, as defined by the new pattern of climate. Nonadaptive fire reduction maintained the contemporary pattern of fire reduction despite the changing patterns of fire risk.

United States population density and per capita wealth are predicted to grow in the next $100 \mathrm{yr}$ and may have a future impact on fire reduction activities (Mullins 2005). To simulate the effects of changes in population density, two cases were considered: population growth and population growth with urbanization. The population growth rate for both runs was based on United Nations projections of $0.7 \% \mathrm{yr}^{-1}$ through 2050 and $0.1 \% \mathrm{yr}^{-1}$ until 2100 (United Nations 2003). Excluding trends in urbanization, this rate was applied to all grid cells. Urbanization was approximated by implementing a $0.06 \% \mathrm{yr}^{-1}$ decline in the lowest $20 \%$ population density grid cells and adding these people to the remaining grid cells (United Nations 2003; United Nations 2004). To estimate the impacts of changes in per capita wealth, an economic growth case was also considered. Based on the U.S. National Assessment, the per capita wealth growth rate was applied in all grid 
cells at $2.44 \% \mathrm{yr}^{-1}$ until 2030 and $2.98 \% \mathrm{yr}^{-1}$ until 2100 (National Assessment Synthesis Team 2001).

The final major factor considered was fuel reduction. Different fuel reduction strategies are currently being promoted in the United States as a way to reduce future fire risk (Hesseln 2000; NFP 2001). These strategies imply potentially different spatial patterns of fuel reduction. For example, the Healthy Forests Initiative promotes the reduction of fuel in high risk areas, while the Communities at Risk program funds fuel reduction projects on the wildland-urban interface. To evaluate the importance of the spatial pattern of fuel reduction, three cases were produced. The first case involved reducing fuel everywhere, at a rate of $0.2 \% \mathrm{yr}^{-1}$. The second case reduced fuel only in areas at risk $\left(B>B^{*}\right)$ at a rate of $0.8 \% \mathrm{yr}^{-1}$. To include both risk and population considerations, a third case was developed in which fuel reduction occurred in areas at risk with relatively high population density $(H>4)$ at a rate of $0.8 \% \mathrm{yr}^{-1}$. This threshold was chosen to exclude the most rural areas but allow for a substantial buffer around urban areas. These rates for fuel reduction were derived by dividing the total fuel reduction area projected by recent federal reports by the approximate land area where the fuel reduction was planned to occur (Laverty and Williams 2000; Healthy Forests 2005).

\subsection{Projections}

Each scenario was used as input to the updated ecosystem models in order to produce projections of the consequences of future fire reduction activities (Figure 5). Each projection was first spun up from 1700 to 2000 following the procedures in Hurtt et al. (Hurtt et al. 2002). In 2001, the fire submodel was switched to the modified fire model described above and run to 2100. Biomass, climate, and fire suppression were dynamic variables that together determined the burned area per year. The resulting projections were evaluated using three metrics for the period 2010 to 2100: burned area, carbon flux, and area at risk. Figure 5 illustrates the range of results for all projections through time for these output metrics.

Across all scenarios, burned area changed from $23000 \mathrm{~km}^{2} \mathrm{yr}^{-1}$ in 2010 to a range of 224 to $1110000 \mathrm{~km}^{2} \mathrm{yr}^{-1}$ in 2100 , with an intermediate peak in burned area at 2020. The range was smaller for cases that excluded catastrophic failure, with a maximum burned area of $206000 \mathrm{~km}^{2} \mathrm{yr}^{-1}$ in 2100. This range in burned area corresponded to a range of carbon fluxes and risk values. Air-to-ground carbon flux for all scenarios started at $0.120 \mathrm{Pg} \mathrm{C} \mathrm{yr}^{-1}$ in 2010 and ended in a range from -0.120 to $0.101 \mathrm{Pg} \mathrm{C} \mathrm{yr}^{-1}$ in 2100 , with an intermediate minimum in 2020 corresponding to the peak in burned area. In cases without catastrophic failure, the carbon flux decreased monotonically to $-0.083 \mathrm{Pg} \mathrm{C} \mathrm{yr}^{-1}$ in 2100 . The fraction of area at risk began at $0.113 \mathrm{yr}^{-1}$ in 2010 and spread to between 0.018 and $0.557 \mathrm{yr}^{-1}$ in 2100. The risk increased despite an increase in burned area because under the assumption of catastrophic failure, all fire-prone areas are at risk due to ineffective fire reduction. Excluding catastrophic failure reduced the maximum risk at the end of the projection by approximately half.

The sensitivity of the model to various scenario cases was determined by pairing simulations where only a single case was changed and calculating the difference for each output metric (Figure 6). Two factors that had the largest impact on total burned area, total carbon flux, and average fire risk from 2010 to 2100 were 

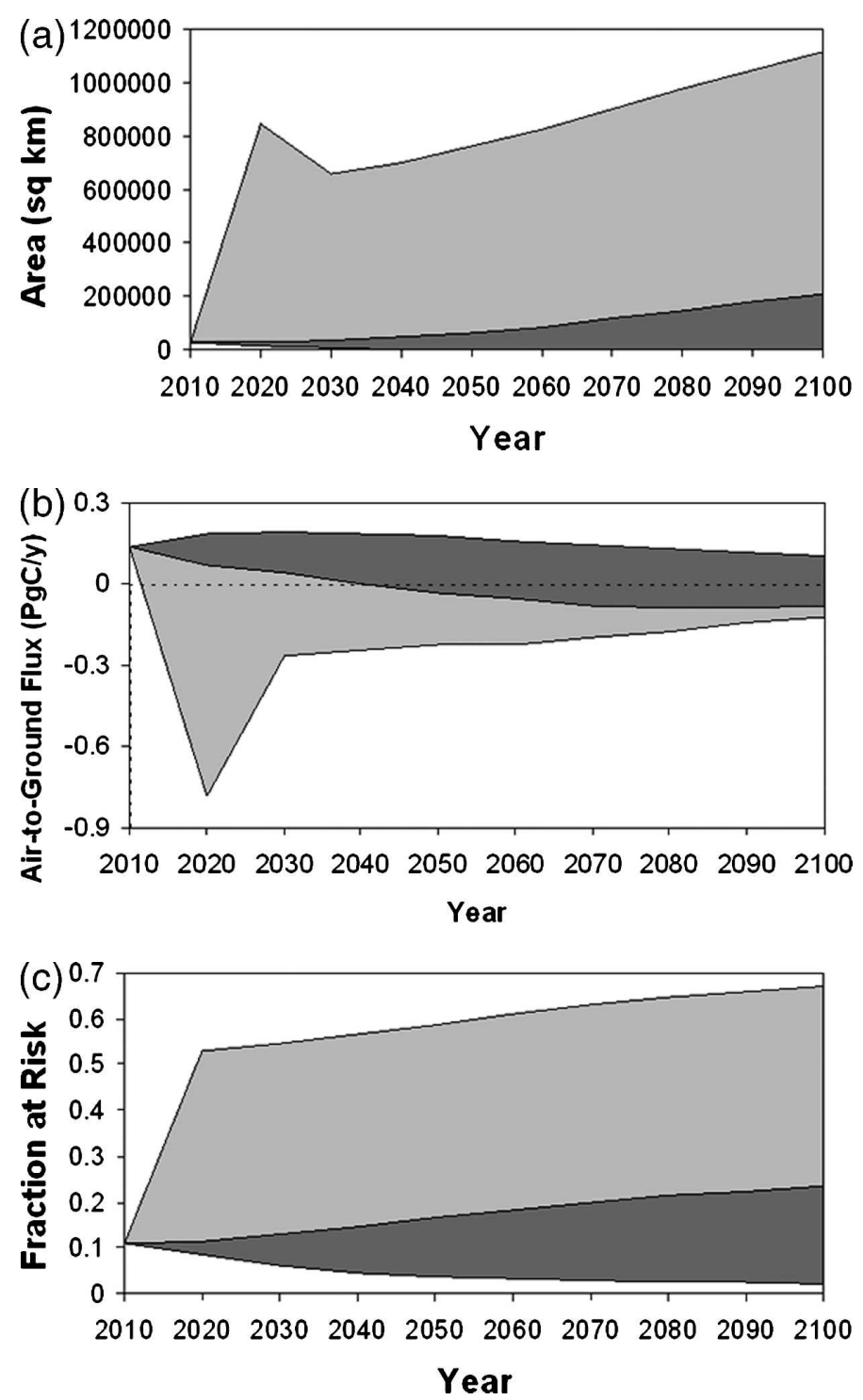

Figure 5. All projections and those without catastrophic reduction failure. All 1620 projections compared to the subset without catastrophic reduction failure for burned area, carbon flux, and fire risk projections from 2010 to 2100 . For each projection, annual burned area was calculated as the integral of burned area $\left(\mathrm{km}^{2} \mathrm{yr}^{-1}\right)$. The change in carbon flux was calculated as the

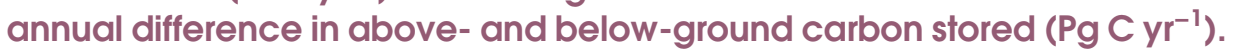
Positive values indicate carbon stored in terrestrial ecosystems and negative values indicate carbon lost to the atmosphere. The fraction of the area of the coterminous United States in which $B(x, y, t)>B^{*}(x, y, t)$ was used to indicate the level of annual fire risk, with a higher fraction indicating greater total risk. The light gray area bounds all 1620 projections, and the dark gray area bounds the 648 projections without reduction failure. (a) Annual burned area projections $\left(\mathrm{km}^{2} \mathrm{yr}^{-1}\right)$, (b) carbon flux projections ( $\mathrm{Pg} \mathrm{C} \mathrm{yr}^{-1}$ ), and (c) annual fire risk projections (fraction $\mathrm{yr}^{-1}$ ). 
Earth Interactions - Volume 11 (2007) • Paper No. 2 • Page 16

(a)

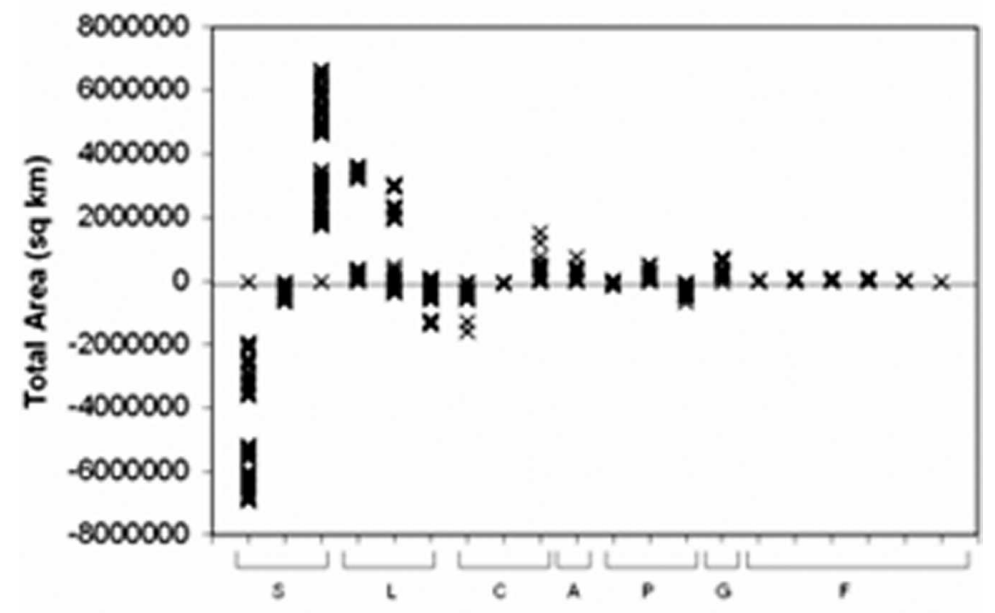

(b)

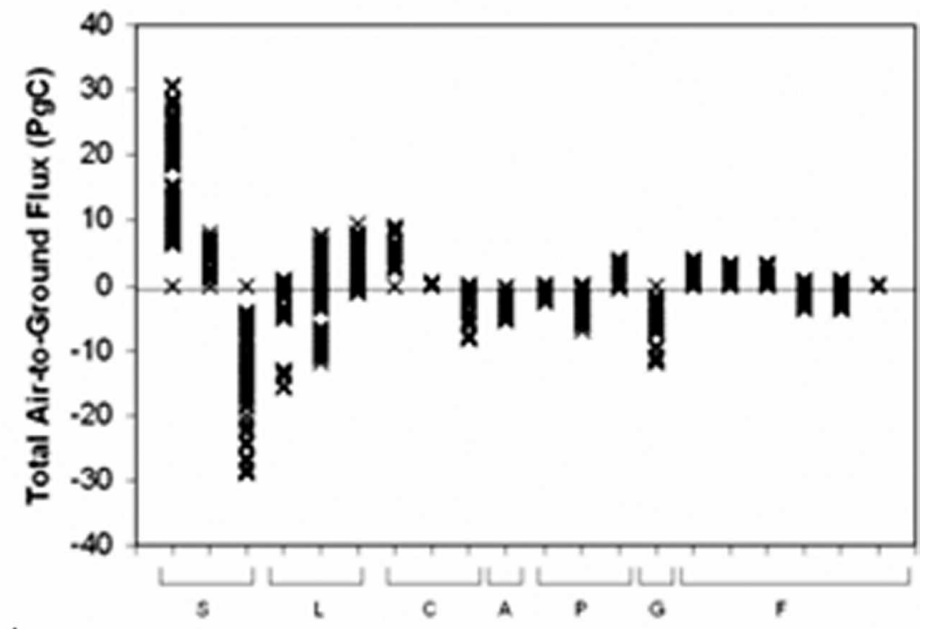

(c)

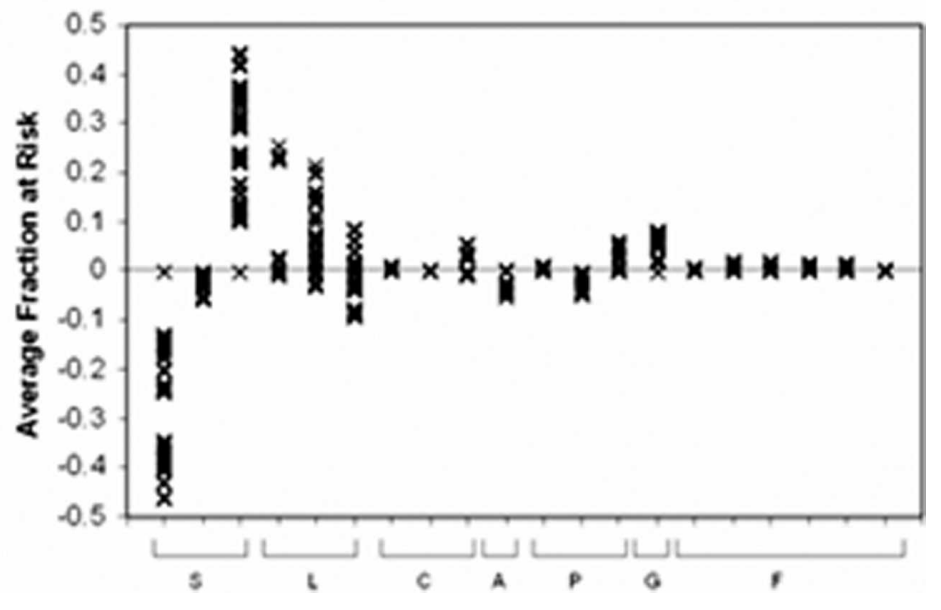


catastrophic reduction failure and land management intensity. Total reduction failure generated $1960000-6700000 \mathrm{~km}^{2}$ more burned area, 6.20-30.9 Pg more carbon lost to the atmosphere, and $0.130-0.470$ more area at risk than cases where fire reduction was effective. Implementing fire reduction activities on less managed lands generated up to $2640000 \mathrm{~km}^{2}$ less burned area, $15.8 \mathrm{Pg}$ less carbon lost to the atmosphere, and 0.254 less area at risk than implementing these activities on all land-use types. Climate change, population change, economic change, and fuel reduction were also sensitive factors; in some cases, the sensitivity differed among output metrics.

\section{Focus on management strategies and indicators of fire reduction}

The probability of catastrophic failure is uncertain and assumed to be small. To isolate the effects of management in the absence of this possibility, we analyzed in detail a subset of 648 projections that excluded reduction failure (Figure 5). For this subset, the impacts of five factors related to human fire reduction activities on the three output metrics were considered (appendix D).

The first analysis evaluated the effects of fire reduction activities by comparing projections from three cases: fire reduction activities on all land-use types, only on primary and secondary lands, and only on pasture and plantation lands. In all metrics, restricting fire reduction activities to more highly managed lands resulted in a decreased range of projections because the domain over which fire reduction was applied was reduced. For example, limiting fire reduction activities to the most highly managed lands (crop, pasture, and plantation) resulted in the smallest range of burned area (5570-155 $000 \mathrm{~km}^{2} \mathrm{yr}^{-1}$ in 2100). Focusing activities on primary and secondary lands produced an intermediate range of burned area (362$198000 \mathrm{~km}^{2} \mathrm{yr}^{-1}$ in 2100), and allowing fire reduction activities to occur on all land-use types resulted in the largest range of projections (224-206 $000 \mathrm{~km}^{2} \mathrm{yr}^{-1}$ in 2100). Restricting fire reduction activities by land-use type contained the negative effects (e.g., urbanization) and limited the positive effects (e.g., fuel reduction) of human activity.

Figure 6. Model sensitivity to scenario options (Table 3) for (a) annual burned area projections integrated from 2010 to $2100\left(\mathrm{~km}^{2}\right)$, (b) annual carbon flux projections integrated from 2010 to 2100 (Pg C), and (c) annual fraction of United States at risk of fire averaged from 2010 to 2100 . Each symbol represents the difference in the projected value for a pair of projections with all scenario options the same except for the pair identified on the horizontal axis. For example, the first set of points represents the difference between pairs of projections with no reduction failure $(\mathrm{SO})$ and with total reduction failure (S1), with each pair having all other parameters equal (e.g., one point equals SOLOCOAOPOGOFO minus S1LOCOAOPOGOFO). The pairs on the horizontal axis are bracketed by scenario option in the panels and are listed in order as follows: S0-S1, SO-S2, S1-S2, LO-L1, LO-L2, L1-L2, $\mathrm{CO}-\mathrm{Cl}$, C0-C2, C1-C2, A0-A1, P0-P2, P0-P1, P1-P2, G0-G1, F0-F1, F0-F2, F0-F3, F1-F2, F1-F3, F2-F3. 
To assess the effectiveness of a fire reduction strategy that is adaptive to changes in patterns of risk, we compared projections from scenarios that included this strategy to those that did not. As expected, adaptive fire reduction generally resulted in less burned area and greater carbon storage than nonadaptive strategies. For example, by 2100 , the maximum total burned area from projections that included adaptive reduction was $54000 \mathrm{~km}^{2}$ less, and $2.03 \mathrm{Pg}$ more carbon was stored than those that did not. The effects of adaptive reduction can be explained by the close match between future fire reduction effort and areas of potential burning. Climate change resulted in new fire-prone regions, and fire reduction activities were focused on these new regions. This resulted in less burned area and therefore more carbon storage than if these regions were allowed to burn. However, adaptive fire reduction also generally resulted in increased rather than decreased fire risk (50\% more by 2100). Under nonadaptive reduction, no reduction effort was applied to the new fire-prone regions and thus the regions burned without increasing risk. Under adaptive reduction, efforts were applied to the new regions, reducing burned area and increasing carbon stored, which in turn increased future risk.

Population and per capita wealth are indicators for the pattern and extent of human reduction activities, since they provide the means to implement fire reduction. The effects of different spatial patterns of population growth on the three metrics were considered. Projections were compared from scenarios with no population growth, scenarios with uniform population growth, and scenarios with population growth combined with urbanization. Population growth reduced burned area (31 $000 \mathrm{~km}^{2} \mathrm{yr}^{-1}$ less) and increased carbon storage (0.045 $\mathrm{Pg} \mathrm{C} \mathrm{yr}^{-1}$ more) but resulted in greater fire risk $\left(0.011 \mathrm{yr}^{-1}\right.$ more fraction at risk). Increased population density led to a lower burned area and thus increased biomass but resulted in little change in the biomass threshold. This resulted in more sites with biomass above the threshold and therefore at risk. Conversely, population growth with urbanization resulted in increased annual burned area (861-206 $000 \mathrm{~km}^{2} \mathrm{yr}^{-1}$ in 2100) and carbon loss $\left(-0.075-0.102 \mathrm{Pg} \mathrm{C} \mathrm{yr}^{-1}\right.$ in 2100) but decreased average risk (0.0180.199 fraction at risk $\mathrm{yr}^{-1}$ in 2100). Under urbanization, burned area decreased in urban areas but increased in rural areas, because there were less people in fireprone rural areas to contribute to fire reduction activities. To assess the effect of economic change on the three metrics, projections from scenarios with no economic growth were compared to scenarios with economic growth. Economic growth resulted in lower annual burned area, carbon loss, and average risk. By 2100 , the maximum burned area in scenarios that included economic growth was up to $44000 \mathrm{~km}^{2} \mathrm{yr}^{-1}$ less than those that did not. These results are consistent across all three output metrics because the effect of economic growth was to increase the biomass threshold everywhere. This reduced burned area and risk, which resulted in increased carbon storage.

To better discern the difference between fuel reduction options, we considered a further subset (40 scenarios) of the projections by eliminating cases with climate change. Projections from scenarios that included fuel reduction were then compared to scenarios that did not. Fuel reduction projections resulted in a very small reduction in annual burned area and average risk $\left(600 \mathrm{~km}^{2} \mathrm{yr}^{-1}\right.$ and 0.007 fraction at risk $\mathrm{yr}^{-1}$ less in 2100), but a relatively large reduction in annual carbon storage (0.02 $\mathrm{Pg} \mathrm{C} \mathrm{yr}^{-1}$ less in 2100). An intercomparison of fuel reduction methods 
Earth Interactions - Volume 11 (2007) - Paper No. 2 • Page 19

showed that fuel reduction in areas at risk was most effective at reducing burned area and risk. This method was also no worse for carbon storage than reducing fuel everywhere.

\section{Discussion}

This work has highlighted the interactions among burned area, carbon storage, and fire risk. Fire risk and carbon storage are linked by the fact that fire reduction results in carbon storage through the buildup of woody vegetation and debris, and stored carbon is a fuel for fires (Figure 1). This linkage leads to a negative feedback, where added carbon storage ultimately elevates burned area, resulting in reduced carbon stocks. This negative feedback can dominate direct effects. Results show that while the expected direct relationships between burned area and risk, and burned area and carbon storage, are represented in the model projections of the future, the direct relationship between carbon storage and risk is not (Figure 7). Although the direct effect of increased carbon elevates fire risk, Figure 7c illustrates that model projections of carbon storage and fire risk were inversely related. This result can be explained by the negative feedback in the system, which overwhelms the direct positive relationship between carbon storage and risk, so carbon actually accumulates in regions with low risk.

Because of the negative feedback, one would expect a system of burned area, carbon storage, and risk to self-regulate in the absence of perturbations or altered forcings. However, human activity has interfered with the natural feedback mechanism through fire reduction activities, leading to altered patterns of carbon storage and burned area (Babbit 1995; Pyne 2001; Hurtt et al. 2002). In addition, climate change has the potential to alter the patterns of risk (Brown et al. 2004). Given that the system is altered, can the current levels of burned area and carbon storage continue, and what are the management options to increase the likelihood that they will continue?

To begin to address these issues, it is important to address the potential for catastrophic fire reduction failure, since it is a possible outcome under conditions of high carbon storage and would have the biggest impact on the system. While we were unable to quantify the potential of catastrophic failure, this study did investigate several relevant management options. Most importantly, the trade-offs among carbon, fire, and risk indicate that carbon storage and burned area should be considered together rather than separately. For example, if fire management was pursued separately, it could lead to low carbon storage through fuel reduction, or elevated risk and burned area in the future due to fuel accumulation. On the other hand, if carbon storage was pursued separately, it could lead to elevated risk and potentially more burned area in the future. Given this situation, collaboration between major national plans for carbon management and fire management should be acknowledged and strongly encouraged (Healthy Forests Restoration Act of 2003; Birdsey 2001; Wofsy and Harris 2002; National Fire Plan 2001).

In addition to suggesting that carbon and fire be managed together, the results of this study are consistent with five other management options (appendix D). First, although fuel reduction is an important management strategy at local and regional scales (Department of Agriculture and Department of the Interior 2001; NASF 2002), it may not be a preferable national strategy. Fuel reduction directly 

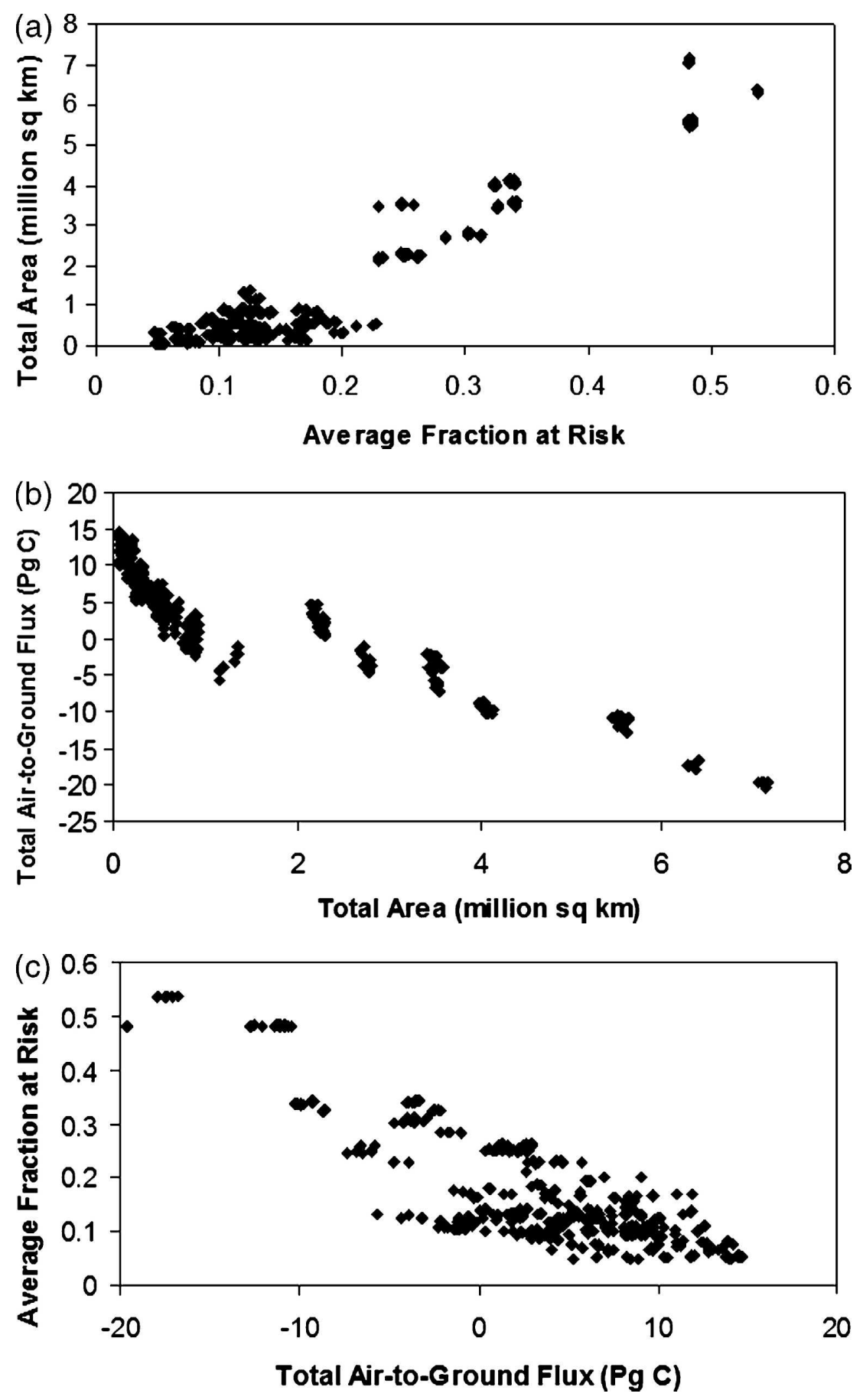

Figure 7. Paired correlations between output metrics. All projections that excluded catastrophic reduction failure were considered. (a) The average fraction of area at risk plotted against the total burned area for each projection over the period 2010-2100. (b) The total air-to-ground flux plotted against the total burned area. (c) The total air-to-ground flux plotted against the average fraction of area at risk. 
Earth Interactions • Volume 11 (2007) - Paper No. 2 • Page 21

decreases carbon storage in ecosystems, which if applied nationally would be a significant carbon loss. In addition, our estimates suggest that the corresponding reduction in burned area would be relatively small. Second, to be efficient, nonfuel-reducing strategies should be adaptive to changes in climate and fuel. Future patterns of fire risk depend on climate, and if projected fire risk regions are accurate, the impacts of climate change should be monitored and fire reduction activities should migrate or expand into the new fire-prone areas. Third, changes in population should be coupled with a redistribution of fire reduction effort. For example, our results indicate that urbanization would lead to increased burned area in sparsely populated areas. Therefore, it should be coupled with increased spending for the protection of rural or wild areas. Fourth, all else being equal, fire reduction activities should be prioritized according to carbon stocks. Areas with high carbon density could result in greater emissions per unit of area burned, as well as greater burned area. This effect was illustrated by the comparison of land management intensities, because generally more carbon is stored in the less managed lands due to the absence of processes such as harvesting and cultivation. Last, the per capita budget allocation for fire reduction as a percentage of the economy should be maintained. This investment is necessary to avoid an increase in burned area in the face of elevated risk from climate change and fuel accumulation. However, under this strategy, fuel does accumulate and so the concerns about future catastrophic fires continue to grow.

This type of study raises several challenges for the robustness of the results: questions about the uncertainty of future conditions, model dependency, and limited data for model calibration. We addressed these issues in the following manner. Burned area, carbon storage, and fire risk in the future depend on several factors that are difficult to predict, such as future climate change, patterns of population, and human activities in the form of land use and fire reduction. We developed scenarios to address these uncertainties. In combination, they formed a set of possible futures on which we could base our analyses. Second, one may question whether the outcomes of the scenarios are overly model dependent. To address this question we parameterized and implemented the fire reduction model in a second ecosystem model, ED (Moorcroft et al. 2001), and obtained similar results (appendix C). Third, the burned area data available for calibration across the entire domain were limited to one year. The many fuel and climate combinations across the gridded domain were used together with a multiyear dataset for a subregion of the domain to calibrate and validate the model, respectively. Based on the analyses of multiple scenarios, models, and datasets, the major results of this study are robust.

There are additional challenges to be addressed in the future. More research is needed to adequately parameterize the probability and magnitude of both very large (catastrophic) and very small $\left(<25 \mathrm{~km}^{2}\right)$ fires. Catastrophic fire reduction failure could potentially produce large fires, making it the most important model factor for future projections in this study. Small fires, which made up only $6.5 \%$ of the total burned area in 2000 (GBA-2000), are common and are known to be important in some systems. Second, improved parameterizations of fuel and climate dependencies are needed to reduce model error and uncertainty. To improve the parameterizations of fuel, a long-term strategy should be based on the comparison of data on fuel and data on burned area [e.g., using data from the Forest 
Earth Interactions - Volume 11 (2007) - Paper No. 2 • Page 22

Inventory and Analysis Program, while tracking the timing and size of fires using Moderate Resolution Imaging Spectroradiometer (MODIS) products when they become available]. These studies should move beyond total biomass as a proxy for fuel and consider fine fuels like litter (Gutsell et al. 2001; Keeley and Fotheringham 2001). To be most useful, corresponding statistics on landscape fragmentation, reduction effort, fuel reduction, climate, and fire history should also be collected and compiled in order to analyze the impact of these factors on burned area. For parameterizations of climate, emphasis should be placed on the development of submodels that depend on intra-annual variability to reduce model error caused by climate averaging, which is of particular importance in strong El Niño years. The only year with available fire data was a La Niña year, which could have led to model underestimation of burned area. To improve the model's value as a prediction tool, it should be calibrated to a broader range of climate variations at a higher temporal resolution. A final challenge for the future is to produce more mechanistic submodels of fire reduction. Since the mixture and type of reduction activities employed to produce the current pattern of burned area in the United States is not well known, the model presented here is more statistically-than mechanistically_based, and the parameters were estimated rather than measured. This has lead to uncertainties in some of the most sensitive aspects of the model.

This study analyzed burned area, carbon storage, and fire risk, as influenced by fire reduction. When evaluating multiple output metrics simultaneously, how can we compare and prioritize them? One approach would be through economics. A basic economic analysis suggests that the value of property in the United States is higher than the current trading price of carbon (Hopkin 2004; PointCarbon 2005). If accurate, this would point toward focusing efforts on reducing burned area and risk, as opposed to storing carbon. However, if the means of this reduction were through fuel reduction, it would be at the expense of carbon storage, which in turn could exacerbate climate change. Alternatively, if non-fuel-reducing approaches are used, the potential catastrophic loss of carbon in large future fires remains a growing risk. The complex nature of the problem and multiple potential feedbacks requires further study as well as management strategies that evaluate carbon storage and fire together rather than separately.

Acknowledgments. We gratefully acknowledge the support of the Department of Homeland Security through their Science \& Technology Fellowship program and the NASA Space Grant Fellowship program. The statements, findings, conclusions, and recommendations are those of the authors and do not necessarily reflect the views of the NASA or the Department of Homeland Security.

\section{Appendix A}

\section{Fire Submodels}

In both models, fires depend on fuel loads and dryness, a common feature of most ecosystem models that include fire (Bachelet et al. 2001; Thonicke et al. 2001). Burned area increases with dryness, which was developed by using published relationships between ecosystem boundaries and climate parameters (Kee- 
Earth Interactions - Volume 11 (2007) - Paper No. 2 • Page 23

ton and Gould 1993; Thornwaite 1948). The reduction factor is a linearly decreasing fraction over time, ranging from 1.0 in 1870 to 0.02 in 1970 , where a smaller value means greater fire reduction.

The specific functions from Equation (A1) in the MIAMI-LU submodel are

$$
\begin{aligned}
& f_{F}(x, y, t)=B(x, y, t), \\
& f_{C}(x, y, t)= \begin{cases}400+40 \times T(x, y, t)-P(x, y, t), & P(x, y, t)<400+40 \times T(x, y, t) \\
0, & \text { otherwise, }\end{cases} \\
& f_{R}(x, y, t)=\frac{t-170}{100},
\end{aligned}
$$

where $B(x, y, t)$ is above-ground biomass density $\left(\mathrm{kg} \mathrm{C} \mathrm{m}^{-2}\right), T(x, y, t)$ is average annual temperature $\left({ }^{\circ} \mathrm{C}\right), P(x, y, t)$ is average annual precipitation $\left(\mathrm{mm} \mathrm{yr}^{-1}\right)$, and $f_{F} \times f_{C}$ is capped at an annual rate of $0.18 \mathrm{yr}^{-1}$ (Hurtt et al. 2002).

The functions in the ED (Hurtt et al. 1998; Hurtt et al. 2004; Albani et al. 2006) submodel differ only in the climate function:

$$
f_{C}(x, y, t)=\left[\frac{\mathrm{DI}(x, y, t)}{30000}\right]^{10},
$$

where $\mathrm{DI}(x, y, t)$ is a dryness index based on soil moisture. The index is cumulative, so that consecutive dry months result in a higher dryness index.

\section{Appendix B}

\section{Simple Goodness-of-Fit Metric}

Likelihood was used as an objective scale to compare the merits of alternative hypotheses for functional forms and parameter values. During model development, a simple likelihood statistic (Edwards 1992) was used as a measure of the goodness-of-fit for model-data comparisons. In particular, we implemented a version of the Metropolis simulated annealing algorithm (Metropolis et al. 1953; Press et al. 1992) to find functional forms and parameter values that maximize the following log-likelihood $(l)$ equation:

$$
l=\sum_{i}\left\{-\ln (\sigma)-\left[\left(M_{i}-F_{i}\right) / 2 \sigma^{2}\right]\right\}
$$

where $i$ is an index for each grid point, $\sigma^{2}$ is the variance, $M_{i}$ is the modeled burned area, and $F_{i}$ is the burned area from the data. We stress that this metric was not used as a formal statistic, but to identify parameters and function forms that enhanced the model's ability to reproduce the data.

\section{Appendix C}

\section{Fire Reduction Function}

The reduction function $f_{R}(x, y, t)$ for a given grid cell and time is represented by the following equations, which are partitioned into differently parameterized func- 
Earth Interactions • Volume 11 (2007) • Paper No. 2 • Page 24

Table C1. Same as in Table 2, but for ED model.

\begin{tabular}{|c|c|c|c|c|c|c|}
\hline \multirow{2}{*}{$\begin{array}{c}\text { ED } \\
\text { parameter }\end{array}$} & \multirow[b]{2}{*}{ Units } & \multicolumn{3}{|c|}{ All } & \multicolumn{2}{|c|}{ Single } \\
\hline & & Best & Low & High & Low & High \\
\hline$p_{1}$ & Population density $\mathrm{km}^{-2}$ & 990 & 4.72 & 999 & 6.99 & $990 *$ \\
\hline$p_{2}$ & $\mathrm{~kg} \mathrm{C} \mathrm{m}{ }^{-2}$ & $4.13 \times 10^{-2}$ & $3.92 \times 10^{-4}$ & 3.28 & $3.42 \times 10^{-2}$ & $2.59 \times 10^{-1}$ \\
\hline$p_{3}$ & Dimensionless & $8.64 \times 10^{-1}$ & $2.37 \times 10^{-5}$ & 3.21 & $7.12 \times 10^{-1}$ & $3.11 *$ \\
\hline$p_{4}$ & Dimensionless & 1.24 & $1.00 \times 10^{-7}$ & 3.93 & $8.10 \times 10^{-2}$ & 2.65 \\
\hline$p_{5}$ & $\mathrm{~kg} \mathrm{C} \mathrm{m}{ }^{-2}$ & $1.18 \times 10^{-1}$ & $6.69 \times 10^{-4}$ & 28.9 & $4.85 \times 102$ & $2.37 \times 10^{-1 *}$ \\
\hline$p_{6}$ & Dimensionless & 1.20 & $1.10 \times 10^{-7}$ & 2.22 & $1.69 \times 10^{-1}$ & $2.20 *$ \\
\hline$p_{7}$ & Dimensionless & 1.23 & $4.38 \times 10^{2}$ & 3.91 & $8.19 \times 10^{-1}$ & 1.57 \\
\hline
\end{tabular}

* Past this maximum value, the parameter does not affect the model output - the likelihood does not change at higher parameter values.

tions by land-use type. The fire reduction functions are represented by $f_{R_{n}}(x, y, t)$ for primary and secondary lands, $f_{R_{p}}(x, y, t)$ for pasture and plantation lands, and $f_{R_{c}}(x, y, t)$ for cropland. The $(x, y, t)$ notation has been removed for compactness, but all terms except for the parameters $\left(p_{1}-p_{7}\right)$ are spatiotemporally dependent. The reduction function is given by

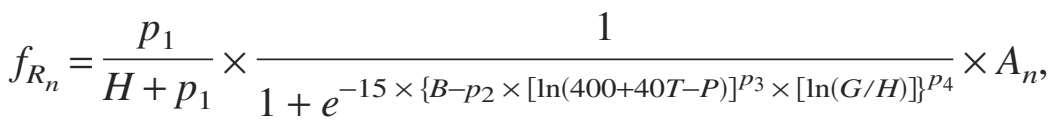

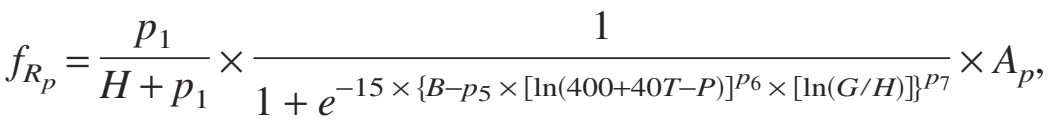

$$
\begin{aligned}
& f_{R_{c}}=0,
\end{aligned}
$$

where $H$ is the population density (people per square kilometer) and $G$ is the gross state product $\left(10^{6} \$\right)$. Here, $A_{n}$ is the percentage of forest land area, $A_{p}$ is the percentage of pasture land area, $A_{c}$ is the percentage of crop land area, and $p_{1}$ to $p_{7}$ are parameters. The values for these parameters as estimated with the MIAMILU ecosystem model are given in Table 2. The new fire submodel was also parameterized in ED, and the values for these parameters are given in Table $\mathrm{C} 1$.

\section{Appendix D}

\section{Projections Partitioned by Case}

There are multiple factors that that determine the cases for each scenario. For each factor, the scenarios were partitioned by case and ranges of projections were compared (Tables D1-D5). Table D1 shows a comparison of projections from three land-use cases for burned area, carbon flux, and fire risk projections. The rows marked "ALL" bound the projections of fire reduction activities on all land-use types, the rows marked "PS" bound the projections of these activities only on primary and secondary lands, and the rows marked "PP" bound the projections of the activities only on pasture and plantation lands. The first column displays the yearly burned area, carbon flux, and fire risk at the year 2100; the second column 
Earth Interactions • Volume 11 (2007) • Paper No. 2 • Page 25

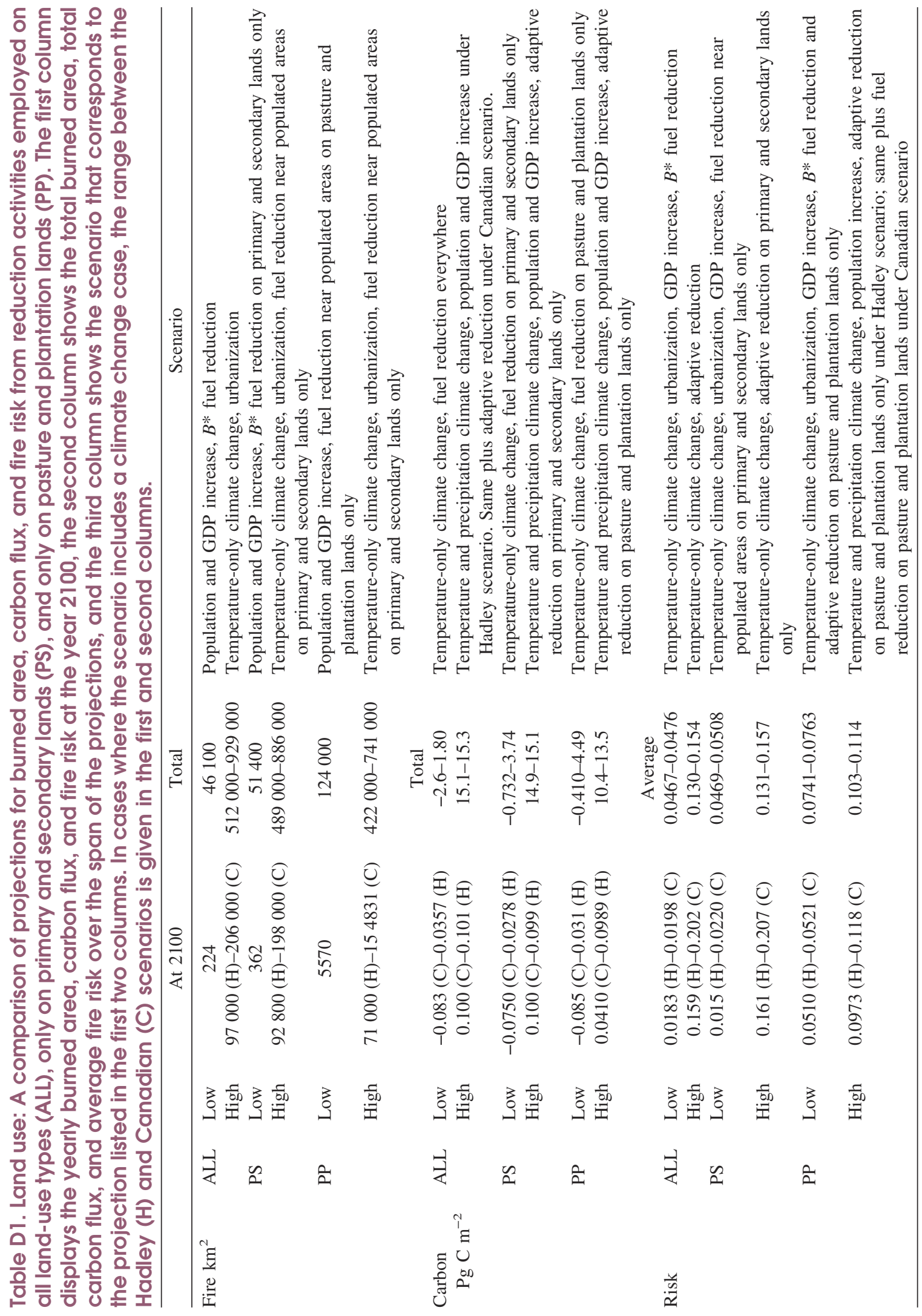


Earth Interactions - Volume 11 (2007) • Paper No. 2 • Page 26

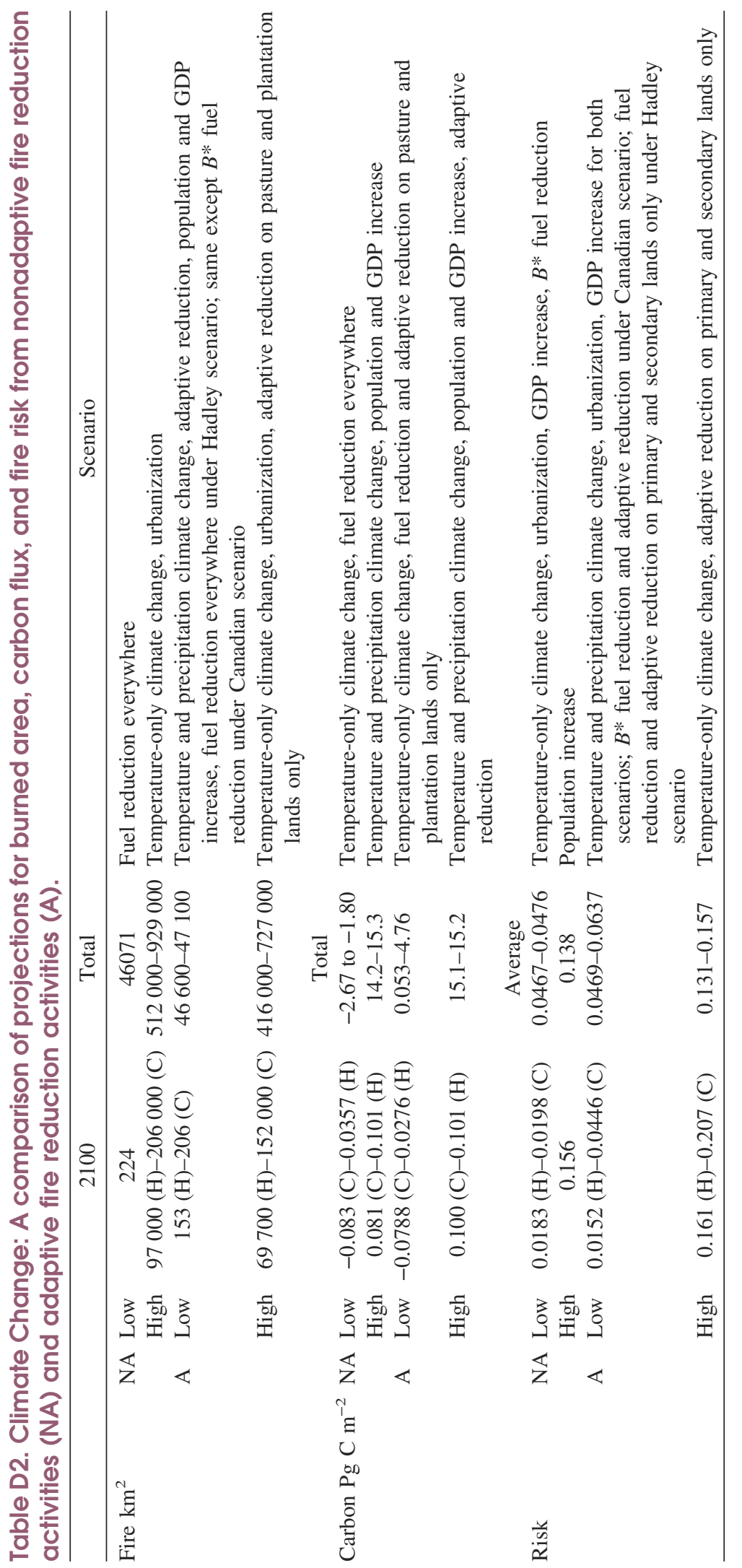


Earth Interactions - Volume 11 (2007) • Paper No. 2 • Page 27

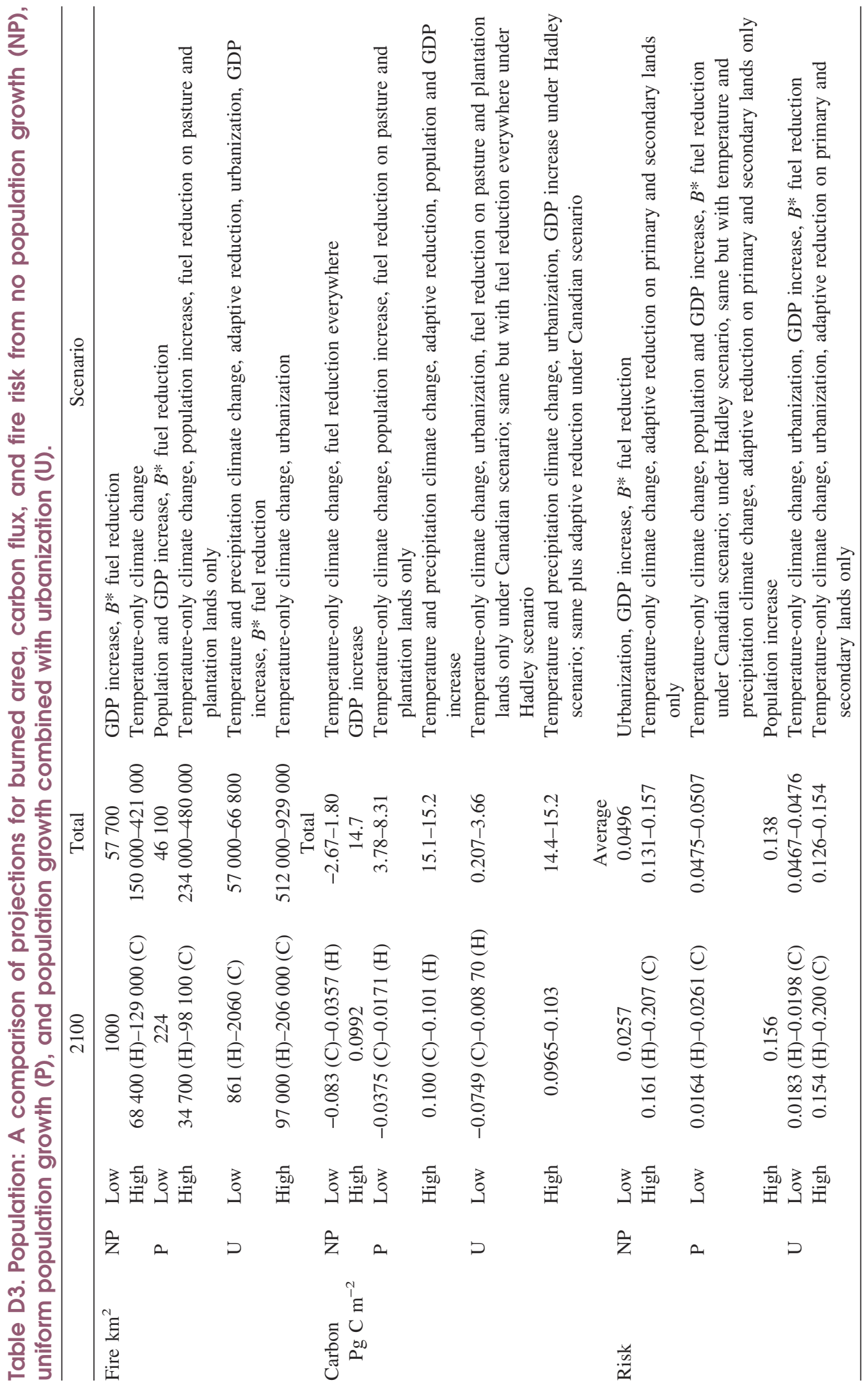


Earth Interactions - Volume 11 (2007) - Paper No. 2 • Page 28

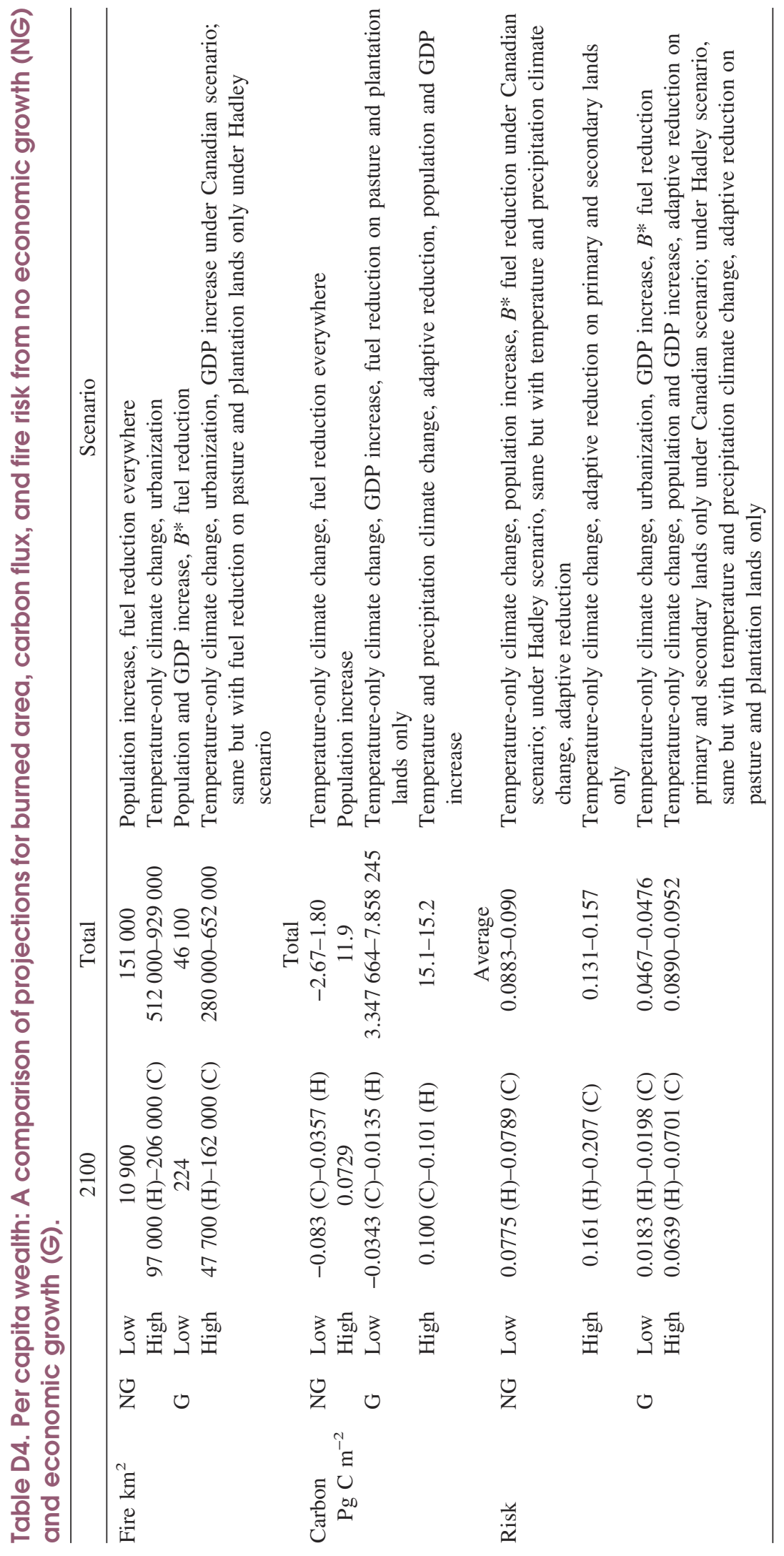


Earth Interactions • Volume 11 (2007) • Paper No. 2 • Page 29

Table D5. Fuel reduction: A comparison of projections for burned area, carbon flux, and fire risk from no fuel reduction activities (NF) and fuel reduction activities (F).

\begin{tabular}{|c|c|c|c|c|c|}
\hline & & & 2100 & Total & Scenario \\
\hline Fire $\mathrm{km}^{2}$ & $\mathrm{NF}$ & $\begin{array}{l}\text { Low } \\
\text { High } \\
\text { Low } \\
\text { High }\end{array}$ & $\begin{array}{r}252 \\
27500 \\
224 \\
26900\end{array}$ & $\begin{array}{c}47800 \\
26900 \\
46000 \\
26400 \\
\text { Total }\end{array}$ & $\begin{array}{l}\text { Population and GDP increase } \\
\text { Business as usual } \\
\text { Population and GDP increase, } B^{*} \text { fuel reduction } \\
B^{*} \text { fuel reduction on pasture and plantation lands only }\end{array}$ \\
\hline $\begin{array}{l}\text { Carbon } \\
\qquad \mathrm{Pg} \mathrm{C} \mathrm{m}^{-2}\end{array}$ & $\mathrm{NF}$ & $\begin{array}{l}\text { Low } \\
\text { High } \\
\text { Low } \\
\text { High }\end{array}$ & $\begin{array}{l}0.0450 \\
0.010 \\
0.0288 \\
0.0987\end{array}$ & $\begin{array}{c}9.48 \\
15.2 \\
6.22 \\
14.4 \\
\text { Average }\end{array}$ & $\begin{array}{l}\text { Business as usual } \\
\text { Population and GDP increase } \\
\text { Fuel reduction everywhere } \\
\text { Population and GDP increase, fuel reduction near populated areas }\end{array}$ \\
\hline Risk & $\mathrm{NF}$ & $\begin{array}{l}\text { Low } \\
\text { High } \\
\text { Low } \\
\text { High }\end{array}$ & $\begin{array}{l}0.0278 \\
0.156 \\
0.0257 \\
0.149\end{array}$ & $\begin{array}{l}0.0511 \\
0.138 \\
0.0490 \\
0.133\end{array}$ & $\begin{array}{l}\text { GDP increase } \\
\text { Population increase } \\
\text { GDP increase, } B^{*} \text { fuel reduction } \\
\text { Population increase, fuel reduction everywhere }\end{array}$ \\
\hline
\end{tabular}

shows the total burned area, total carbon flux, and average fire risk over the span of the projections; and the third column shows the scenario that corresponds to the projection listed in the first two columns. In cases where the scenario includes a climate change case, the range between the Hadley $(\mathrm{H})$ and Canadian $(\mathrm{C})$ scenarios is given in the first and second columns. In most cases the scenarios that produce the bounding projections are the same, but if the minimum or maximum Hadley scenario was different from the minimum or maximum Canadian scenario, both scenarios are listed in the third column. Table D2 shows a comparison between two adaptive reduction cases for burned area, carbon flux, and fire risk projections from 2010 to 2100, respectively. Table D3 shows a comparison among three population density cases, and Table D4 shows a comparison between two per capita wealth cases. A further subset (40 scenarios) of the future projections was produced by eliminating cases with climate change. In Table D5, fuel reduction cases were compared to non-fuel-reduction scenarios for burned area, carbon flux, and fire risk projections from 2010 to 2100, respectively.

\section{References}

Albani, M., D. Medvigy, G. C. Hurtt, and P. R. Moorcroft, 2006: The contributions of land-use change, $\mathrm{CO}_{2}$ fertilization, and climate variability to the Eastern U.S. carbon sink. Global Change Biol., in press.

Allen, C. D., and Coauthors, 2002: Ecological restoration of southwestern ponderosa pine ecosystems: A broad perspective. Ecol. Appl., 12, 1418-1433.

Alkire, C., 2004: The Federal Wildland Fire Budget: Let's prepare, not just react: Emphasis on reduced financial and ecological costs. Wilderness Society Publication, 35 pp. [Available online at http://www.wilderness.org/Library/Documents/upload/Wildland-Fire-Budgetfull.pdf.]

Babbit, B., 1995: To take up the torch. American Forests, July/August, 17-18, 59, 63.

Bachelet, D., J. Lenihan, C. Daly, R. Nielson, D. Ojima, and W. Parton, 2001: MC1: A dynamic vegetation model for estimating the distribution of vegetation and associated ecosystem fluxes of carbon, nutrients, and water. Pacific Northwest Station General Tech. Rep. PNW- 


\section{Earth Interactions • Volume 11 (2007) • Paper No. 2 • Page 30}

GTR-508, USDA Publication, $101 \mathrm{pp}$. [Available online at http://www.fsl.orst.edu/dgvm/ mcgtr508.pdf.]

— - and Coauthors, 2003: Simulating past and future dynamics of natural ecosystems in the United States. Global Biogeochem. Cycles, 17, 1045, doi:10.1029/2001GB001508.

BEA, cited 2004: Regional economic accounts: Gross state product, 2000. Bureau of Economic Analysis. [Available online at http://www.bea.gov/bea/regional/gsp.htm.]

Beltrami, E., 1987: Mathematics for Dynamic Modeling. Academic Press, 277 pp.

Birdsey, R. A., 2001: Forest management and carbon sequestration. Proc. Program on Regional Partnerships in Terrestrial Carbon Sequestration Workshop, Lexington, KY, DOE, NETL, and CSiTE.

Brower, J. E., and J. H. Zar, 1984: Field and Laboratory Methods for General Ecology. 2d ed. William C. Brown Publishers, 226 pp.

Brown, T. J., B. L. Hall, and A. L. Westerling, 2004: The impact of twenty-first century climate change on wildland fire danger in the western United States: An applications perspective. Climate Change, 62 (1-3), 365-388.

Burgan, R. E., P. L. Andrews, L. S. Bradshaw, C. H. Chase, R. A. Hartford, and D. J. Latham, 1997: WFAS: Wildland fire assessment system. Fire Manage. Notes, 57 (2), 14-17.

Cardoso, M. F., G. C. Hurtt, B. Moore III, C. A. Nobre, and E. M. Prins, 2003: Projecting future fire activity in Amazonia. Global Change Biol., 9, 656-669.

Dale, V. H., and Coauthors, 2001: Climate change and forest disturbances. Bioscience, 51, $723-$ 734.

Dellasalla, D. A., J. E. Williams, C. D. Williams, and J. F. Franklin, 2004: Beyond smoke and mirrors: A synthesis of fire policy and science. Conserv. Biol., 18, 976-986.

Department of Agriculture and Department of the Interior, 2001: Urban wildland interface communities within the vicinity of federal lands that are at high risk from wildfire. Federal Register, Vol. 66, No. 160, 53 pp. [Available online at http://www.fireplan.gov/reports/351358-en.pdf.]

Dodge, M., 1972: Forest fuel accumulation-A growing problem. Science, 177, 139-142.

Edwards, A. W. F., 1992: Likelihood. Expanded ed. Johns Hopkins University Press, 275 pp.

Firewise, 2001: Firewise Communities Participant Workbook: Making Sensible Choices in the Wildland/Urban Interface. $2 \mathrm{~d}$ ed. Firewise Communities, $34 \mathrm{pp}$.

Grégoire, J.-M., K. Tansey, and J. M. N. Silva, 2003: The GBA-2000 initiative: Developing a global burned area database from SPOT-VEGETATION imagery. Int. J. Remote Sens., 24, 1369-1376.

Grissino-Mayer, H. D., 1999: Modeling fire interval data from the American southwest with the Weibull distribution. Int. J. Wildland Fire, 9, 37-50.

Gutsell, S. L., E. A. Johnson, K. Miyanishi, J. E. Keeley, M. Dickinson, and S. R. J. Bridge, 2001: Varied ecosystems need different fire protection. Nature, 409, 977.

Healthy Forests, cited 2005: Healthy forests progress report. The Healthy Forests Initiative. [Available online at http://www.healthyforests.gov/projects/.]

Hesseln, H., 2000: The economics of prescribed burning: A research review. Forest Sci., 46, 322-334.

Hopkin, M., 2004: Emissions trading: The carbon game. Nature, 432, 268-270.

Houghton, R. A., J. L. Hackler, and K. T. Lawrence, 1999: The U.S. carbon budget: Contributions from land-use change. Science, 285, 574-578.

,-- , and -2000 : Changes in terrestrial carbon storage in the United States. 2: The role of fire and fire management. Global Ecol. Biogeogr., 9, 145-170.

Hurtt, G. C., P. R. Moorcroft, S. W. Pacala, and S. A. Levin, 1998: Terrestrial models and global change: Challenges for the future. Global Change Biol., 4, 581-590.

—, S. W. Pacala, P. R. Moorcroft, J. Caspersen, E. Shevliakova, R. A. Houghton, and B. Moore III, 2002: Projecting the future of the U.S. carbon sink. Proc. Natl. Acad. Sci. USA, 99, 1389-1394. 


\section{Earth Interactions • Volume 11 (2007) • Paper No. 2 • Page 31}

- R. Dubayah, J. Drake, P. Moorcroft, S. Pacala, and M. Fearon, 2004: Beyond potential vegetation: Combining lidar remote sensing and a height-structured ecosystem model for improved estimates of carbon stocks and fluxes. Ecol. Appl., 14, 873-883.

Kasischke, E. S., N. L. Christensen Jr., and B. J. Stocks, 1995: Fire, global warming, and the Carbon balance of boreal forests. Ecol. Appl., 5, 437-451.

Kaufman, Y. J., C. Ichoku, L. Giglio, S. Korontzi, D. A. Chu, W. M. Hao, R. R. Li, and C. O. Justice, 2003: Fire and smoke observed from the Earth Observing System MODIS instrument—Products, validation, and operational use. Int. J. Remote Sens., 24, 1765-1781.

Keane, R. E., P. Morgan, and S. W. Running, 1995: Fire-BCG-A mechanistic ecological process model for simulating fire succession on coniferous forest landscapes of the Northern Rocky Mountains. Forest Service Research Paper INT-RP-484, USDA Publication, 122 pp.

Keeley, J. E., and C. J. Fotheringham, 2001: History and management of crown-fire ecosystems: A summary and response. Conserv. Biol., 15, 1561-1567.

Keeton, W. T., and J. L. Gould, 1993: Biological Science. 5th ed. Norton, 1194 pp.

Kistler, R., and Coauthors, 2001: The NCEP-NCAR 50-Year Reanalysis: Monthly means CDROM and documentation. Bull. Amer. Meteor. Soc., 82, 247-268.

Korontzi, S., J. McCarty, T. Laboda, S. Kumar, and C. O. Justice, 2006: Global distribution of agricultural fires in croplands from 3 years of Moderate Resolution Imaging Spectroradiometer (MODIS) data. Global Biogeochem. Cycles, 20, GB2021, doi:10.1029/2005GB002529.

Langenfelds, R. L., R. J. Francey, B. C. Pak, L. P. Steele, J. Lloyd, C. M. Trudinger, and C. E. Allison, 2002: Interannual growth rate variations of atmospheric $\mathrm{CO}_{2}$ and its $\delta \mathrm{C} 13, \mathrm{H}_{2}, \mathrm{CH}_{4}$ and CO between 1992 and 1999 linked to biomass burning. Global Biogeochem. Cycles, 16, 1048, doi:10.1029/2001GB001466.

Laverty, L., and J. Williams, 2000: Protecting people and sustaining resources in fire-adapted ecosystems: A cohesive strategy. The Forest Service Management Response to the General Accounting Office Rep. GAO/RCED-99-65, USDA Publication, 85 pp.

Leenhouts, B. 1998: Assessment of biomass burning in the coterminous United States. Conserv. Ecol., 2 (1). [Available online at http://www.ecologyandsociety.org/vol2/iss1/art1/.]

Lenihan, J. M., C. Daly, D. Bachelet, and R. P. Neilson, 1998: Simulating broad-scale fire severity in a dynamic global vegetation model. Northwest Sci., 72, 91-103.

Li, C., M. Ter-Mikaelian, and A. Perera, 1997: Temporal fire disturbance patterns on a forest landscape. Ecol. Modell., 99, 137-150.

Malamud, B. D., G. Morein, and D. L. Turcotte, 1998: Forest fires: An example of self-organized critical behavior. Science, 281, 1840-1842.

McCarthy, M. A., A. M. Gill, and R. A. Bradstock, 2001: Theoretical fire-interval distributions. Int. J. Wildland Fire, 10, 73-77.

Meeson, B. W., F. E. Corprew, J. M. P. McManus, D. M. Meyers, J. W. Closs, K. J. Sun, D. J. Sunday, and P. J. Sellars, 1995: ISLSCP Initiative I: Global Data Sets for Land-Atmosphere Models 1987-1988. National Aeronautics and Space Administration, Washington, DC, Vols. $1-5$, CD-ROM.

Metropolis, N., A. W. Rosenbluth, M. N. Rosenbluth, A. H. Teller, and E. Teller, 1953: Equation of state calculations by fast computing machines. J. Chem. Phys., 21, 1087-1092.

Moorcroft, P. R., G. C. Hurtt, and S. W. Pacala, 2001: A method for scaling vegetation dynamics: The ecosystem demography model (ED). Ecol. Monogr., 71, 557-586.

Mullins, G. W., Ed., cited 2005: The I-Zone: A human dimension of wildland fire. Communicator's Guide: Wildland Fire. [Available online at http://www.nifc.gov/preved/comm_guide/ wildfire/fire_9.html.]

Murdiyarso, D., M. Widodo, and D. Suyamoto, 2002: Fire risks in forest carbon projects in Indonesia. Sci. China Ser. C, 45, 65-74.

NASF, 2002: Concept paper: Communities at risk. National Association of State Foresters, 2 pp. [Available online at http://www.stateforesters.org/reports/CommAtRisk.pdf.]

National Assessment Synthesis Team, 2001: Climate Change Impacts on the United States: The 


\section{Earth Interactions • Volume 11 (2007) • Paper No. 2 • Page 32}

Potential Consequences of Climate Variability and Change: Report for the US Global Change Research Program. Cambridge University Press, 620 pp.

National Atlas, cited 2004a: Federal lands of the United States, U.S. Census Database, 2000. The National Atlas of the United States of America. [Available online at http://nationalatlas.gov/ $\mathrm{mld} / \mathrm{ce} 2000 \mathrm{t} . \mathrm{html}$.

— cited 2004b: Population density, U.S. Census Database, 2000. The National Atlas of the United States of America. [Available online at http://nationalatlas.gov/mld/ce2000t.html.]

National Historic Lookout Register, cited 2004: Lookouts and towers listed on the National Historic Lookout Register: By state, province and country. [Available online at http:// www.firetower.org/content.html.]

NFP, 2001: A collaborative approach for reducing wildland fire risks to communities and the environment-10-year comprehensive strategy. USDA Publication, $24 \mathrm{pp}$.

— , 2004: Large fire reduction costs: Strategies for cost management. A Report to the Wildland Fire Leadership Council from the Strategic Issues Panel on Fire Reduction Costs, USDA Publication, $12 \mathrm{pp}$.

Nielson, R. P., 1995: A model for predicting continental-scale vegetation distribution and water balance. Ecol. Appl., 5, 362-385.

NIFC, cited 2005: Total fires and acres 1960-2004. National Interagency Fire Center. [Available online at http://www.nifc.gov.]

NOAA-CIRES, cited 2005: CDC derived NCEP reanalysis products spectral. NOAA-CIRES Climate Diagnostics Center. [Available online at http://gcmd.nasa.gov/records/GCMD_ NOAA_CDC039.html.]

NWCG, 1996: Glossary of wildland fire terminology. PMS 205, NFES 1832, Sponsored by USDA, DOI, and the National Association of State Foresters, $148 \mathrm{pp}$.

Pacala, S. W., and Coauthors, 2001: Consistent land- and atmosphere-based U.S. Carbon sink estimates. Science, 292, 2316-2320.

Page, S. E., F. Siegert, J. O. Rieley, H. D. V. Boehm, A. Jaya, and S. Limin, 2002: The amount of carbon released from peat and forest fires in Indonesia during 1997. Nature, 420, 61-65.

Parsons, J., 1981: The role of fire management in maintaining natural ecosystems. Proc. Fire Regimes and Ecosystem Properties, Forest Service General Tech. Rep. WO-26, Honolulu, HI, Forest Service, Department of Agriculture, 469-488.

PointCarbon, cited 2005: EU ETS price assessment. [Available online at http://www.pointcarbon. com/category.php?categoryID $=377$.]

Press, W. H., B. P. Flannery, S. A. Teukolsky, and W. T. Vetterling, 1992: Numerical Recipes in C: The Art of Scientific Computing. Cambridge University Press, 994 pp.

Pyne, S. J., 2001: The fires this time, and next. Science, 294, 1005-1006.

— , P. Andrews, and R. Laven, 1996: Introduction to Wildland Fire. 2d ed. John Wiley \& Sons, 769 pp.

Ramankutty, N., and J. A. Foley, 1999: Estimating historical changes in global land cover: Croplands from 1700 to 1992. Global Biocheochem. Cycles, 13, 997-1027.

Schimel, D., and D. Baker, 2002: Carbon cycle: The wildfire factor. Nature, 42, 29-30.

- and Coauthors, 2001: Recent patterns and mechanisms of carbon exchange by terrestrial ecosystems. Nature, 414, 169-172.

Schmidt, K. M., J. P. Menakis, C. C. Hardy, W. J. Hann, and D. L. Bunnell, 2002: Development of course-scale spatial data for wildland fire and fuel management. Forest Service General Tech. Rep. RMRS-GTR-87, USDA Publication, xx pp.

Schoenberg, F. P., R. Peng, Z. Huang, and P. Rundel, 2003: Detection of non-linearities in the dependence of burn area on fuel age and climatic variables. Int. J. Wildland Fire, 12, 1-6.

Sellers, P. J., and Coauthors, 1995: ISLSCP Initiative I-Global Data Sets for Land-Atmosphere Models, 1987-1998. National Aeronautics and Space Administration, Washington, DC, Vol. 1, CD-ROM. 


\section{Earth Interactions • Volume 11 (2007) • Paper No. 2 • Page 33}

Sitch, S., and Coauthors, 2003: Evaluation of ecosystem dynamics, plant geography, and terrestrial carbon cycling in the LPJ dynamic global vegetation model. Global Change Biol., 9, 161185.

Spring, D., J. Kennedy, and R. M. Nally, 2005: Optimal management of a flammable forest providing timber and carbon sequestration benefits: An Australian case study. Aust. J. Agric. Resour. Econ., 49, 303-320.

Thonicke, K., S. Venevsky, S. Sitch, and W. Cramer, 2001: The role of fire disturbance for global vegetation dynamics: Coupling fire into a Dynamic Global Vegetation Model. Global Ecol. Biogeogr., 10, 661-677.

Thornwaite, C. W., 1948: An approach to a rational classification of climate. Geogr. Rev., 38, 55-94.

United Nations, 2003: Urban and rural areas 2003. United Nations Department of Economic and Social Affairs, Population Division, New York, NY, 2 pp. [Available online at http:// www.un.org/esa/population/publications/wup2003/2003Urban_Rural.pdf.]

— , 2004: World population to 2300. ST/ESA/SER.A/236, United Nations Department of Economic and Social Affairs, Population Division, New York, NY, 254 pp.

van der Werf, G. R., J. T. Randerson, G. J. Collatz, L. Giglio, P. S. Kasibhatla, A. F. Arellano Jr., S. C. Olsen, and E. S. Kasischke, 2004: Continental-scale partitioning of fire emissions during the 1997 to 2001 El Niño/La Niña period. Science, 303, 73-76.

Venevsky, S., K. Thonicke, S. Sitch, and W. Cramer, 2002: Simulating fire regimes in humandominated ecosystems: Iberian Peninsula case study. Global Change Biol., 8, 984-998.

Westerling, A. L., A. Gershunov, T. J. Brown, D. R. Cayan, and M. D. Dettinger, 2003: Climate and wildfire in the western United States. Bull. Amer. Meteor. Soc., 84, 595-695.

Williams, R. J., L. B. Hutley, G. D. Cook, J. Russell-Smith, A. Edwards, and X. Y. Chen, 2004: Assessing the carbon sequestration potential of mesic savannas in the Northern Territory, Australia: Approaches, uncertainties and potential impacts of fire. Funct. Plant Biol., 31, 415-422.

Wofsy, S. C., and R. C. Harris, 2002: The North America Carbon Program (NACP). Report of the NACP Committee of the U.S. Interagency Carbon Cycle Science Program, U.S. Global Change Research Program, Washington, DC, 62 pp.

Earth Interactions is published jointly by the American Meteorological Society, the American Geophysical Union, and the Association of American Geographers. Permission to use figures, tables, and brief excerpts from this journal in scientific and educational works is hereby granted provided that the source is acknowledged. Any use of material in this journal that is determined to be "fair use" under Section 107 or that satisfies the conditions specified in Section 108 of the U.S. Copyright Law (17 USC, as revised by P.IL. 94-553) does not require the publishers' permission. For permission for any other form of copying, contact one of the copublishing societies. 